\title{
CONSTRUCTIONAL AND ACCUMULATIONAL MODES OF FABRICS IN SELECTED PENNSYLVANIAN ALGAL-DOMINATED BUILDUPS IN EASTERN KANSAS, MIDCONTINENT, U.S.A.
}

\author{
ELIAS SAMANKASSOU \\ Université de Fribourg, Département de Géosciences, Géologie et Paléontologie, Pérolles, CH-1700 Fribourg, Switzerland \\ e-mail: elias.samankassou@unifr.ch \\ AND \\ RONALD R. WEST \\ Kansas State University, Department of Geology, Thompson Hall, Manhattan, Kansas 66506, U.S.A. \\ e-mail: rrwest@ksu.edu
}

\begin{abstract}
Algal buildups from five stratigraphic intervals in the Pennsylvanian of eastern Kansas, Midcontinent, U.S.A., display three basic fabrics based on their: a) dimension, b) morphology, c) fossil content, d) algal growth forms, and e) nature of framework cavities.

Type 1. Constructional mounds composed of cup-shaped in situ algal growth forms are typically small bioherms, either isolated (e.g., Frisbie Limestone Member) or thickened intervals within carbonate banks (e.g., Sniabar Limestone Member), and are basically formed by phylloid green algae. Fossil diversity is very low. Mud and cement fill the abundant small intercup voids within individual mounds. Calcareous sponges, crinoids, and bryozoans, probably cavity dwellers, fill the larger intermound cavities between the smaller mounds.

Type 2. Constructional mounds of algae with undulatory growth forms are basically red algae with recognizable thalli characteristics of Archaeolithophyllum, and, only rarely, of phylloid green algae. Buildups of this kind are laterally persistent. Thickening of the banks is generally recognizable at a large scale (ten of meters to kilometers). Smaller, meter-scale bioherms constructed of algae with undulatory growth forms do not occur in the sites studied. Fossil diversity is higher than in type (1) mounds, with calcareous sponges, brachiopods, and bryozoans common throughout the mound, rather than exclusively in cavities between small mounds of the type 1 cup-shaped algae. When built by green algae (e.g., parts of the Captain Creek Limestone Member), mounds have a lower diversity than those constructed by red algae (e.g., Spring Hill Limestone Member). Solitary corals, calcareous sponges, and bryozoans occur attached to the walls of the cavities. The abundance of open pores is striking.

Type 3. Mounds of accumulated algae with undulatory growth forms are formed by the red algae Archaeolithophyllum missouriense, Archaeolithophyllum lamellosum, and the green alga Eugonophyllum. Depositional relief is not visible on the outcrop, but large-scale variations in bank thickness are notable (e.g., lower part of the Captain Creek Limestone Member). Bryozoans and Thartharella (a probable worm tube) are common. Multiple types of cavities occur, and most are cement-filled.

Although the mound types differ in their form, fossil content, and type and distribution of voids, they share an overall common peloidal clotted matrix that accumulated in specific areas, along with an abundance of gravity-defying peloidal micritic structures in the matrix, and of thin crusts within marine cement that may be related to microbial activity. Microbes probably played a crucial role in carbonate precipitation and in lithification of algal-dominated buildups.
\end{abstract}

\section{INTRODUCTION}

Phylloid algal buildups, widespread in the Pennsylvanian, have generally been assigned to a single, simple genetic mode. A few authors have not ruled out the reef-building potential of phylloid algae (e.g., Fagerstrom, 1987). Samankassou and West $(2000,2002)$ recently described a unique constructional mode of a phylloid algal mound from the Frisbie limestone in eastern Kansas and suggested that detailed study of these buildups may aid in understanding the growth mode and the role of algae in mound construction, and also help differentiate between different types of algal mounds. Buildups in five different Pennsylvanian limestone units (Sniabar, Winterset, Frisbie, Spring Hill, and Captain Creek) in eastern Kansas are the focus of this study. Limestones of the Kansas City and Lansing groups are major hydrocarbon producers in central and western Kansas. A considerable amount of this production is from algal limestones, which are the subject of this paper.

\section{METHODS}

150 polished slabs and large thin sections $(10 \mathrm{~cm} \times 15 \mathrm{~cm}$ in size) were analyzed from approximately 200 samples collected from mounds and rocks associated with each of them. Microfacies analysis, with an emphasis on fossil associations, helped interpret the growth modes of these algal mounds. First each of the mounds is described and interpreted as to depositional environment, and then the different mound types are characterized, on the basis of the role of algae and relative biodiversity. Finally, factors controlling the different growth forms are discussed.

\section{LOCATION AND STRATIGRAPHY}

Pennsylvanian limestones in Kansas are well known for their algal content, and where these algal limestones are especially thick (3-24 $\mathrm{m}$ ) they have been referred to as algal banks or mound complexes (Heckel and Cocke, 1969). Such mounds or banks are particularly common in the limestones of Missourian age that are exposed in outcrops that extend from the southwest to the northeast across the eastern part of the state (Fig. 1). All of the sites studied are exposures along road cuts.

Of the five limestone units studied for this paper, three [Sniabar (S), Winterset (W), and Frisbie (F)] are members of the Kansas City Group and the other two [Spring Hill (SH) and Captain Creek (C)] are members of the overlying Lansing Group (Fig. 2). 


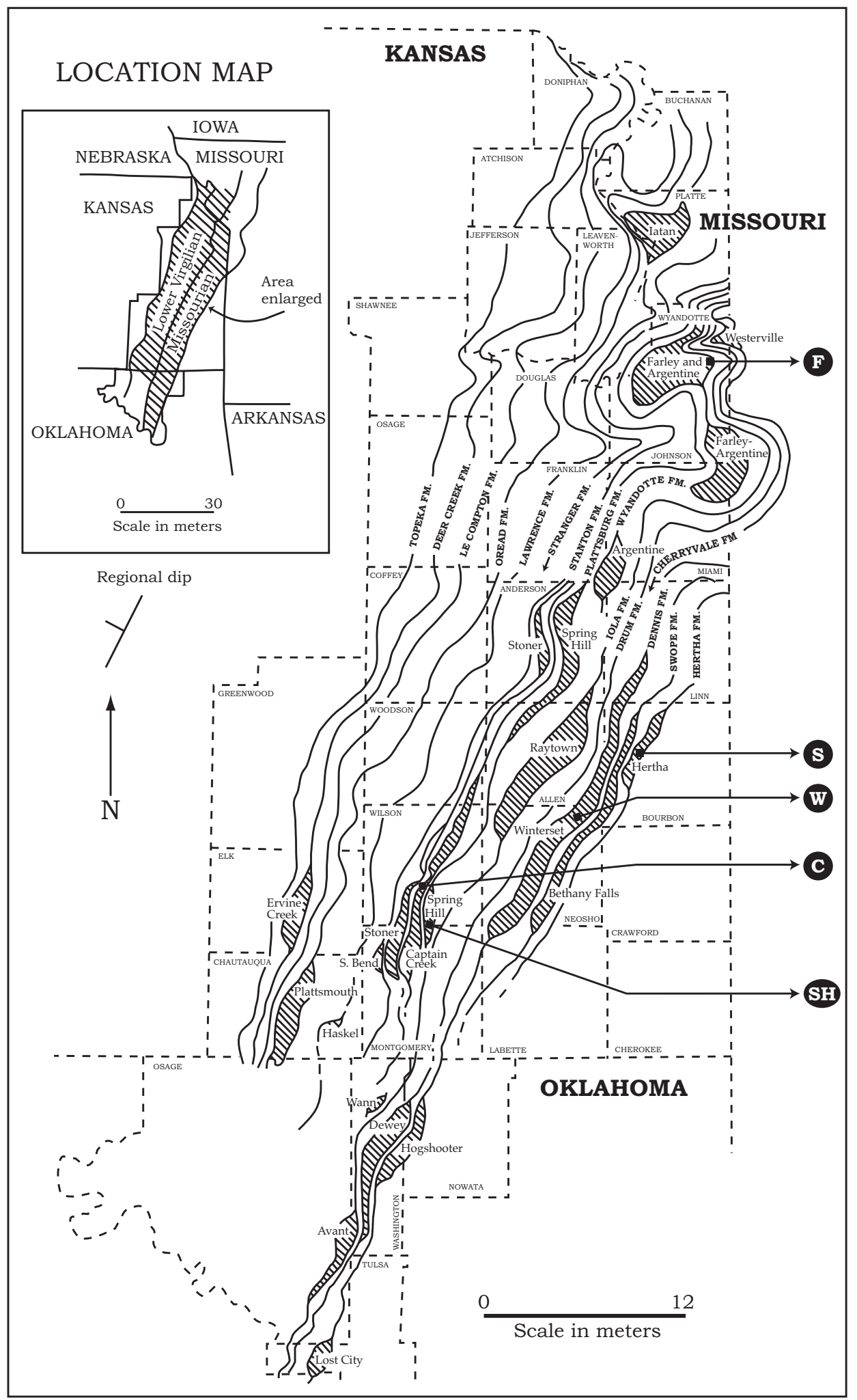

FIG. 1.-Distribution of Missourian and lower Virgilian phylloid algal buildups in eastern Kansas and adjacent states. Wide areas with oblique lining represent outcrop of mound complexes; narrow lines represent non-mound facies; all traces are straightened and simplified. Arrows indicate that the Cherryvale and Stranger Formations continue in a southwestern direction. Location of the five limestone sites considered herein are: $\mathrm{S}=$ Sniabar, $\mathrm{W}=$ Winterset, $\mathrm{F}=$ Frisbie, $\mathrm{C}=\mathrm{Captain} \mathrm{Creek}$, and $\mathrm{SH}=\mathrm{Spring}$ Hill. Modified from Heckel and Cocke (1969, fig. 2). 


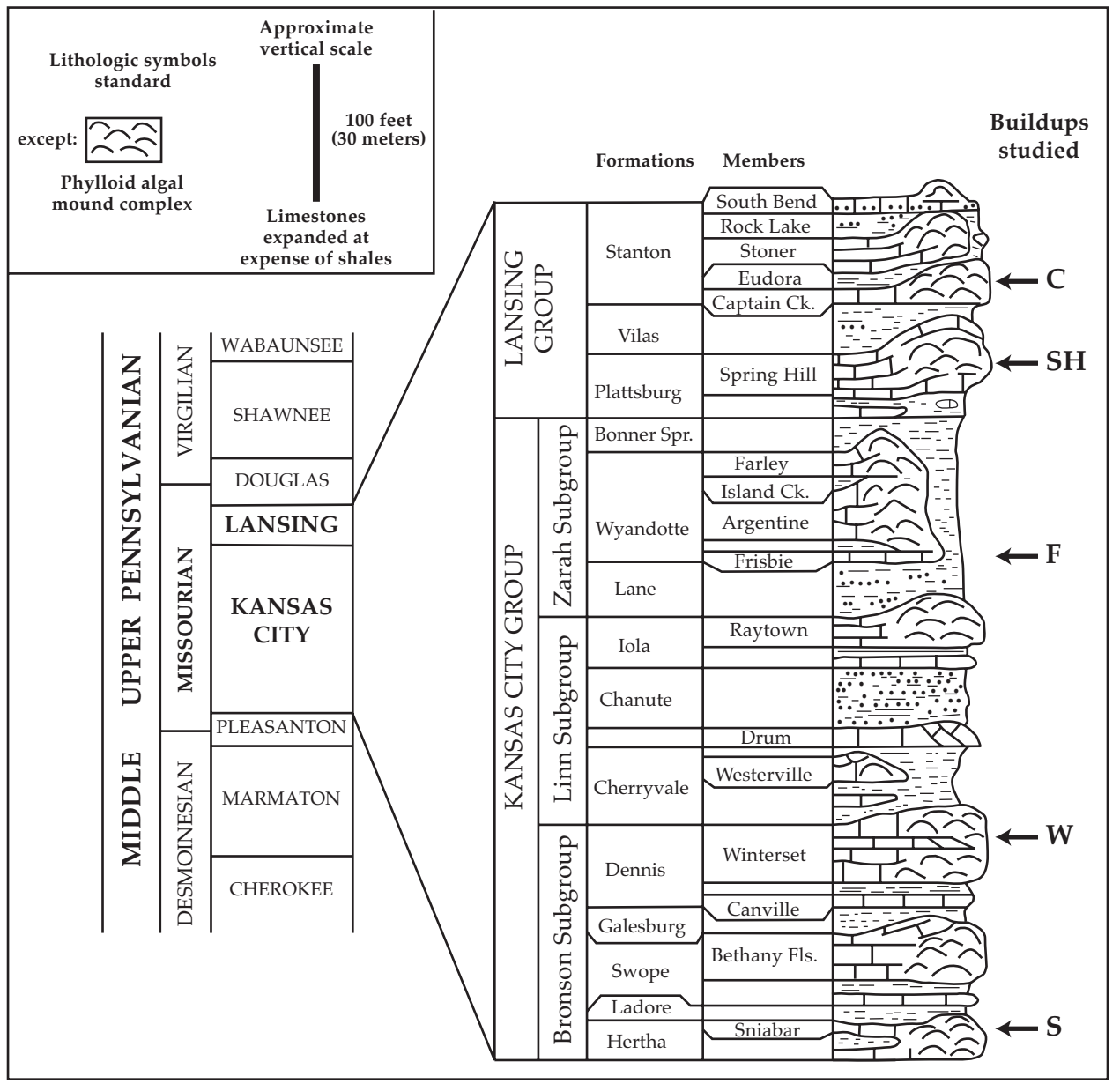

FIG. 2.-Generalized stratigraphic sequence of Kansas City and Lansing Groups (Missourian) in eastern Kansas modified from Heckel and Cocke (1969, fig. 1). Letters along right side refer to the five limestone members studied (see Fig. 1 for location) as follows: $\mathrm{S}=$ Sniabar, $\mathrm{W}=$ Winterset, $\mathrm{F}=$ Frisbie, $\mathrm{SH}=$ Spring Hill, and $\mathrm{C}=$ Captain Creek.

\section{DESCRIPTION OF BUILDUPS}

\section{Sniabar Limestone Member}

The Sniabar Limestone Member of the Hertha Limestone (Fig. 2) represents the late regressive phase of the Hertha cyclothem, which may record a minor transgression (sea-level rise) that ended the detrital input that prevailed during deposition of the underlying Mound City shale at the study locality (Heckel, 1999). The Sniabar limestone is approximately $9 \mathrm{~m}$ thick (Fig. 3), with a paleosol at the top (Watney et al., 1995; Watney et al., 1989; Heckel, 1999).

The lower part of the sequence consists of well-bedded and nodular limestones (Fig. 3). The bedded limestone is a bioclastic packstone and grainstone, and the strongly abraded fossils include crinoids, algae (Epimastopora?), ostracodes, and rare foraminifers. The nodular limestone is a wackestone with lower biotic diversity. There is no framework, e.g., macroscopically recognizable upright algal growth forms, or peloidal clotted fabrics. Thin layers of Beresella-like algal thalli are intercalated with peloidal areas. Accessory fossils include brachiopods, rare bryozoans, and the foraminifer Tuberitina.

In the upper massive part of the sequence, buildups are architecturally complex (amalgamation of smaller banks; Watney et al., 1995), and algae, bryozoans, and syringoporid corals are the main mound builders. Three zones can be distinguished vertically:

1. The lower part of the mound consists, volumetrically, of minor cup-shaped algal thalli and of the more common undulatory types (Figs. 4C, 5A). Peloids occur, although those linked to frameworks are rare (Fig. 5A). Other rare fossils are brachiopods, bryozoans, and tubular foraminifers.

2. The middle part is commonly recrystallized fenestellid and cystoporate (Fig. 5C) bryozoans and corals. Accessory fossils include smaller foraminifers and brachiopods. Peloids are common, but cement is more abundant than in the lower part. Syringoporid coral colonies obviously built large (decimeterscale) patches (Fig. 4B; see also Tedesco and Wanless 1989, 1995) and formed frameworks, with pores filled by mud and cement but lacking other fossils (Fig. 5D).

3. The upper part includes cup-shaped phylloid algae, clearly in growth position (Fig. 4D). Individual cups, within the algalbuilt framework, are filled with mud, and locally fragments of algal thalli occur within the individual cups. Cement-filled voids commonly occur beneath undulatory algal umbrellas. 


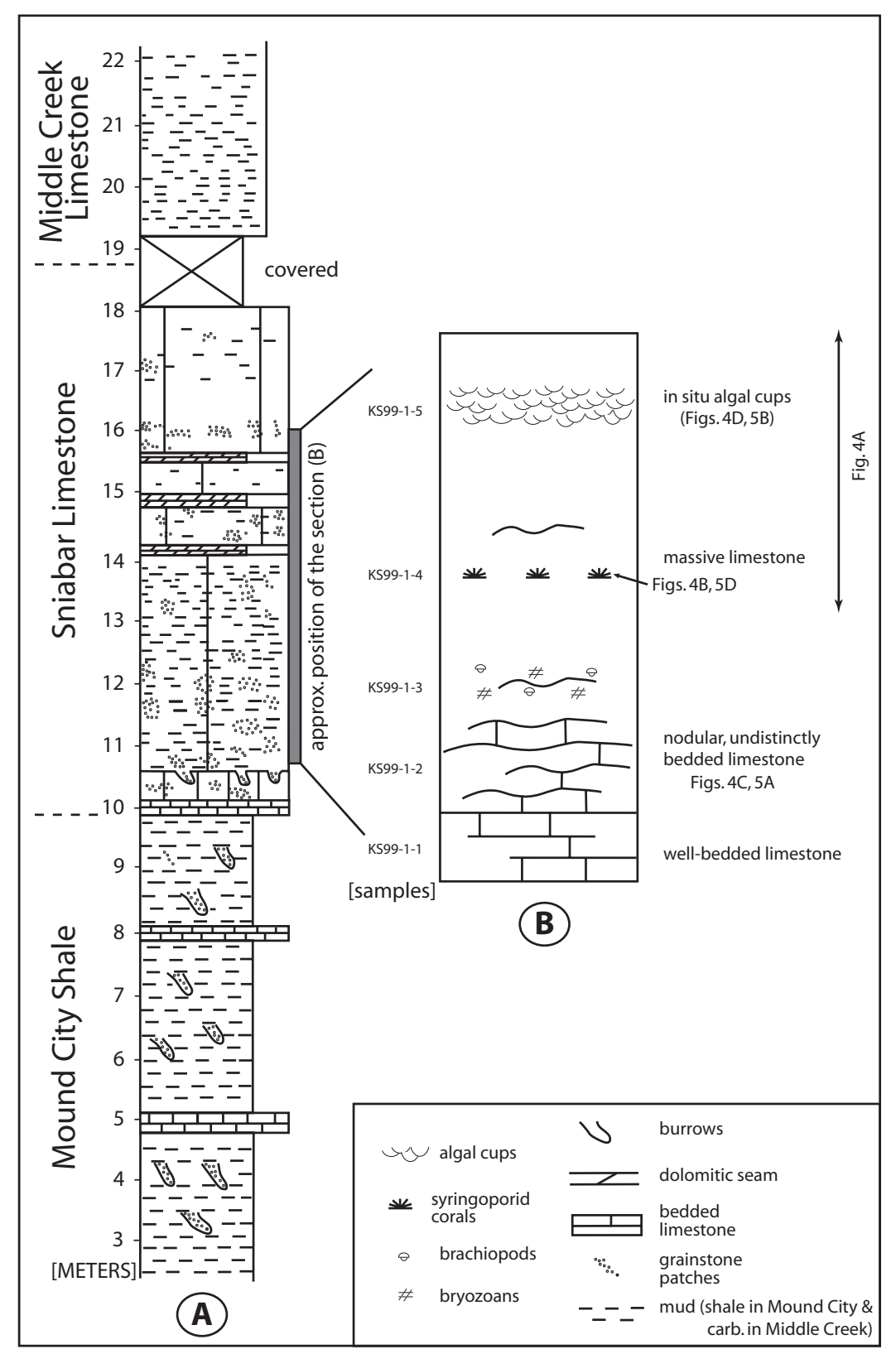

FIG. 3.-Log of exposure of Sniabar limestone at roadcut along Kansas Highway 3 south of Uniontown, Kansas; Center of North half, Sec. 34, T.25S., R.22E., Bourbon County, Kansas, p. 165-172 in Watney et al. (1989) (see Fig. 1).

In some thin sections, more convex-upward undulatory algae with very thin thalli cover irregular, "filament"-rich, spongelike areas (Fig. 5B). The "filaments" could be fragments of encrustations, possibly microbial in origin. The significance of these structures is not clear. Algal thalli are partly encrusted by dark layers, probably microbial in origin. Fossils in the phylloid algal frameworks include brachiopods and smaller foraminifers.

\section{Winterset Limestone Member}

The Winterset Limestone Member is the upper member of the Dennis Limestone (Fig. 2) and comprises the regressive limestone of the Dennis cyclothem in its lower part and probably the transgressive part of the overlying Hogshooter cycle in its upper part, as shown by Felton and Heckel (1996); see also Heckel (1999). The occurrence of an algal-bank complex in the Winterset limestone was recognized by Harbaugh (1962) and described by Frost $(1969,1975)$.

Two of the Winterset limestone exposures studied are differentiated vertically into an unevenly bedded algal-dominated lower part, an intermediate cross-bedded unfossiliferous oolitic grainstone, and a massive algal-dominated upper part (Fig. 6A). Lateral variations in thickness are visible at the outcrop sampled (Fig. 7). The algal-dominated, unevenly bedded lower part is approximately $2.5 \mathrm{~m}$ thick at the illustrated (Fig. 7) exposure and 

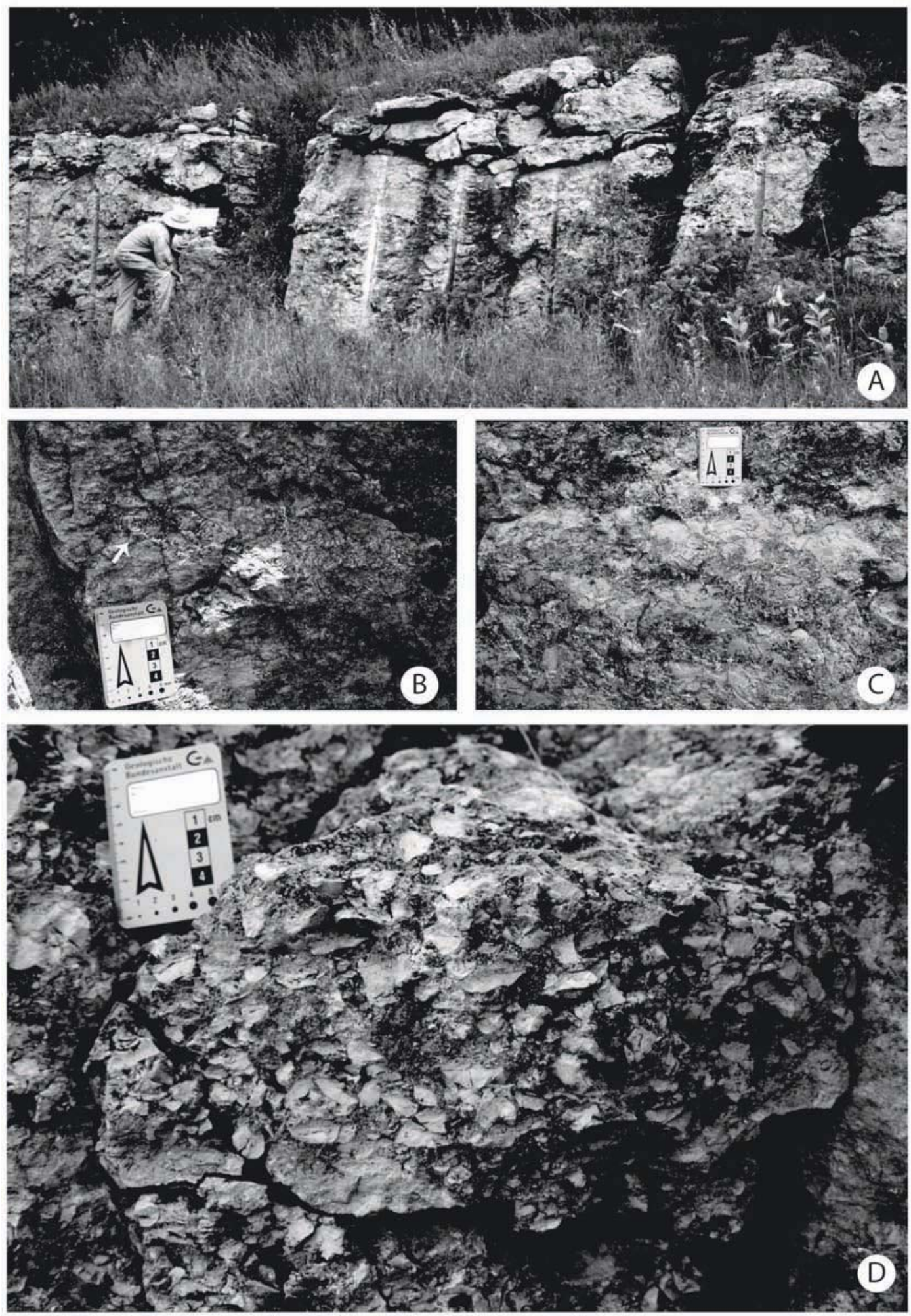

FIG. 4.-Photographs of Sniabar limestone mound. A) Depositional relief on Sniabar limestone as exposed at roadcut along Kansas Highway 3 south of Uniontown, Kansas (see Fig. 1). Thickening to the right is real and not dip. B) Decimeter-scale syringoporid corals aligned subparallel to bedding plane (arrow above scale). (See Fig. 3B for stratigraphic horizon). C) Algal-dominated limestone, with algae (dark) in a mud matrix (white). Note that mud matrix is volumetrically much more important than algal thalli. D) In situ algal cups filled with light-colored mud close to one another, forming a delicate framework (see also microfacies in Fig. 5A). (See Fig. 3B for stratigraphic horizon). Note differences between cup-shaped forms of thalli versus the undulatory thalli lacking a definite growth form in Part C, resulting in overall greater porosity (black areas) in Part D than in Part C. 

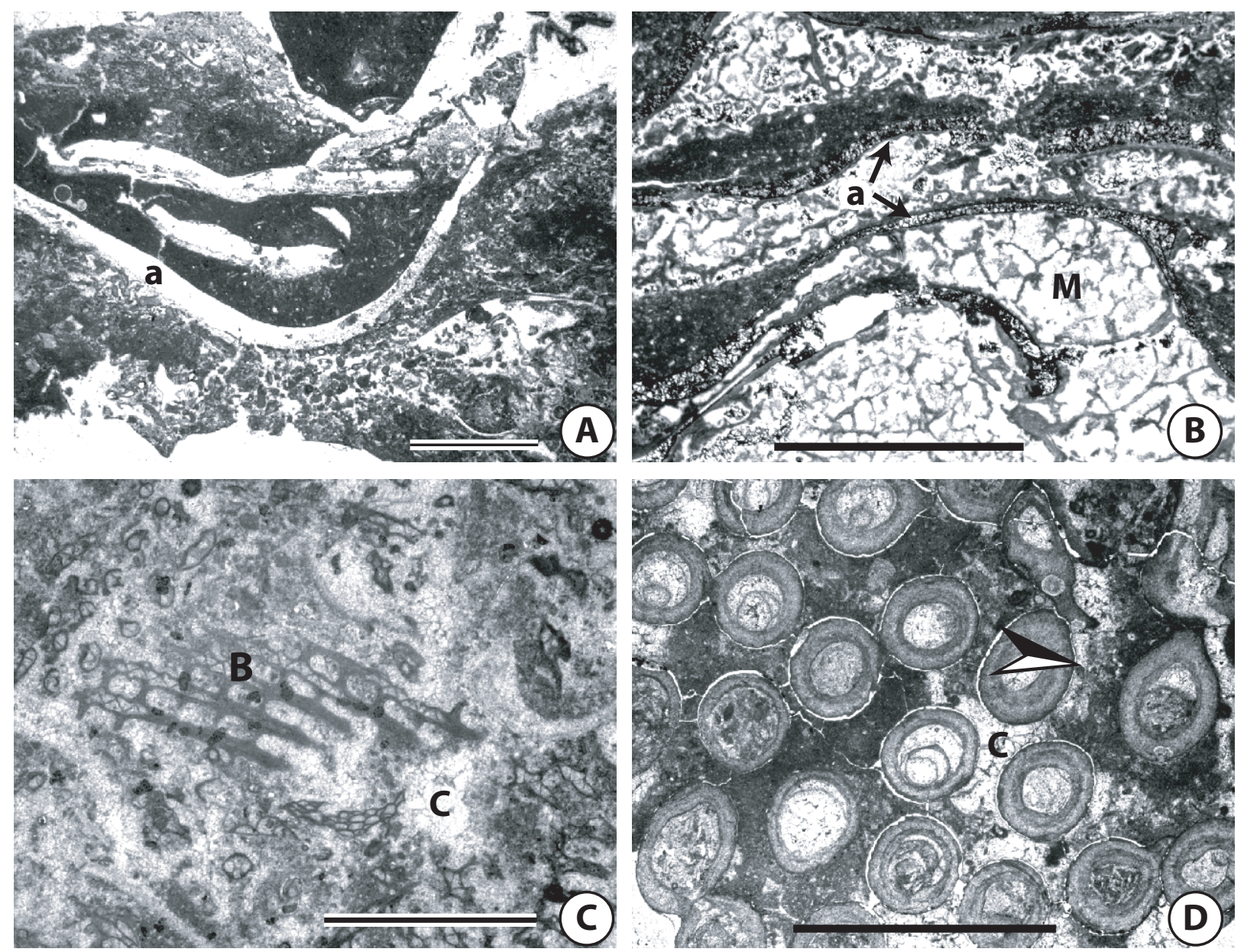

FIG. 5.-Photomicrographs of Sniabar mound south of Uniontown, Kansas. A) Cup-shaped algal thalli (a) in peloid-rich matrix. Some algal-thallus fragments are included in matrix that filled cups. Mud-filling in cups is dark at base and becomes lighter upward. Scale bar is $5 \mathrm{~mm}$. B) Undulatory thalli (a) seemed to have grown on a sponge-like structure (M) that may have resulted from microbial activity. The succession of " $\mathrm{M}$ " to " $a$ " to "peloidal filling" is striking throughout the thin section of the interval studied. Scale bar is $5 \mathrm{~mm}$. C) Bryozoan (B) boundstone dominated by fenestellids along with cystoporates (playing a binding role). Note the patchy distribution of solution pores (C). Scale bar is $2.5 \mathrm{~mm}$. D) Coral boundstone. Framework pores are filled with peloidal mud, finely crystalline (dark and uniform) to coarsely crystalline cement (C). Transition from peloidal fillings to cements is not sharp (arrow). Section parallel to bedding plane. Scale bar is $5 \mathrm{~mm}$.

includes an algal boundstone. Large, undulatory and broken algal thalli are common (Fig. 7C). Most algal boundstones exhibit a low biotic diversity, but fossils are common in the Winterset mounds and includebryozoans, brachiopods, crinoids, ostracodes, and smaller foraminifers. Bryozoans are dominant in specific intervals where they occur with mud and cement.

The upper part, $1.5 \mathrm{~m}$ thick at this exposure, is indistinctly bedded to massive wackestone dominated by algal thalli (Fig. 6A, B), and it appears to be the result of an accumulation of algal thalli rather than a structure constructed by algae in growth position. Smaller foraminifers and ostracodes are the only fossils other than algae that were encountered in the upper part.

Discrete tabulate coral bioherms, approx. $0.4 \mathrm{~m}$ thick, occur at the same level within the sequence (Fig. 6B, C). Colonies of syringoporid corals dominate the framework of this characteristic microfacies (Fig. 7B), along with some solitary rugose corals (Fig. 6C). The mud matrix includes small bioclasts of unknown origin.

\section{Frisbie Limestone Member}

The Frisbie Limestone Member is the lowest member of the Wyandotte Limestone (Fig. 2) and the transgressive member of the Wyandotte cyclothem (Heckel, 1999).

The Frisbie limestone consists of one or two massive beds totalling $1.5 \mathrm{~m}$ or less in thickness. Samankassou and West (2002) have recently described the construction of some algal mounds in the Frisbie limestone in detail; thus only the key features are summarized below.

Frisbie mounds are small but display definite depositional topography (Fig. 8). They are characterized by a framework of cup-shaped algal thalli that grew closely packed and juxtaposed next to and above one another. The mounds differ from the overlying non-mound facies, which also contain algal thalli (Fig. 9B). The largest Frisbie mound measured is $1.4 \mathrm{~m}$ thick and $4.2 \mathrm{~m}$ across (Fig. 8) and is a composite mound composed of smaller mounds (mini-mounds) of centimeter scale. The framework fab- 


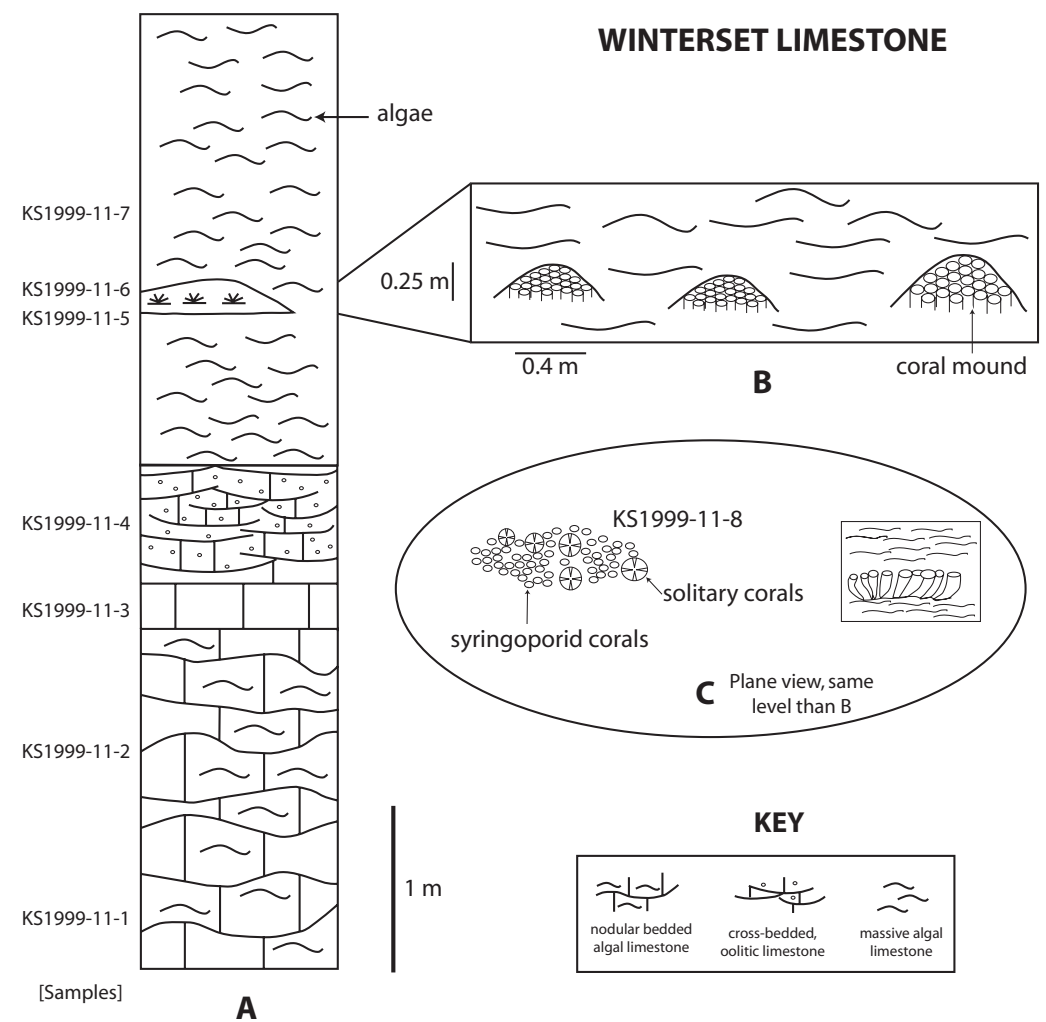

FIG. 6.-Diagrams of Winterset limestone (Fig. 1, 2) exposed at roadcut along Kansas Highway 39/U. S. Highway 59 East of Chanute, Kansas; NW1/4, NW1/4, Sec. 23, T.27S., R.20E., Neosho Co., Kansas, p. 63 in Harbaugh (1962). A) Measured section showing position of B) subparallel-aligned syringoporid coral mounds with C) associated solitary corals. See Fig. 7 for photographs of details.

ric of the individual thalli (Fig. 10A) in the small mounds includes intercup voids that are filled with: (1) peloidal grains, both in peloidal clotted wackestone and peloid grainstone (which seem to represent biotic encrustation around blades that are continuous with the similar micrite cement on the underside of the blades); (2) early-marine cement linings; (3) micritic cements, often gravity defying; and (4) mudstone (see Samankassou and West, 2002).

Intramound areas, up to several decimeters in size, are filled with crinoidal debris, sponges, bryozoans, brachiopods, and nonpeloidal grains (Fig. 10B, C). Fossils (partly broken; Fig. $10 \mathrm{C}$ ) in these intramound cavities may represent remains of a cryptic biota, similar to the sponges, crinoids, and bryozoans reported from many extant and fossil reef crypts (see Wood, 1999, and references therein). Although invertebrate fossils have been found only within intramound areas, these areas do not contain any fragments of algal thalli. The overlying Argentine Limestone Member is a bioclastic wackestone, and differs from the mound limestone in having a greater biotic diversity and in lacking both an algal framework and peloidal grains (cf. Fig. 9A, B).

\section{Spring Hill Limestone Member}

The Spring Hill Limestone Member is the upper member of the Plattsburg Limestone (Figs. 2, 11) and the regressive limestone of the Plattsburg cyclothem (Heckel, 1999). The buildup in the interval studied (Figs. 11, 12A) consists of crudely bedded limestones that contain multiple cavities (Fig. 12B, C).
The lower part of the section (between 30 and 50 feet in Fig. 11) is a bryozoan boundstone. Peloidal clotted areas and cementfilled voids account for $30 \%$ of the rock volume. Fanlike, probably marine cements occur in some cavities. Large clumps (peloids?) occur in the cement. The matrix is nearly free of fossils, except for a few Shamovella, ostracodes, and Thartharella, a problematic fossil but possibly a worm tube (cf. Wahlman, 1988; Samankassou, 2001). Three meters above the base of the section studied an Archaeolithophyllum-bryozoan boundstone is dominant(Fig. 13A, B). Peloids and microbial cement are important components (Fig. 13A, B). The highly diverse bryozoans include fenestellids and cystoporates. Other fossils encountered were sponges, Shamovella, crinoid debris, small brachiopods, sessile foraminifers (especially Tuberitina), and ostracodes. Biotic diversity within the mound is generally higher than in the lower part of this section and in the other algal mounds examined. In the uppermost part of this section are thin crusts that may represent Archaeolithophyllum lamellosum. The percentage of Thartharella increases upward in the section.

The upper, marly part of the section consists predominantly of mud-rich bryozoan boundstone (Fig. 13C). It contains more bioclasts and less cement compared to the previously described part, but no algae (Fig. 13C). Farther upward, sponges are common, along with Shamovella. The uppermost part of the mound contains more crinoidal debris. Only very small patches of cement are present.

The capping facies is a fusulinid-algal dominated packstone to grainstone (Heckel, 1978) with coated fragments of phylloid algae, the dasyclad green alga Epimastopora, and multiple fora- 

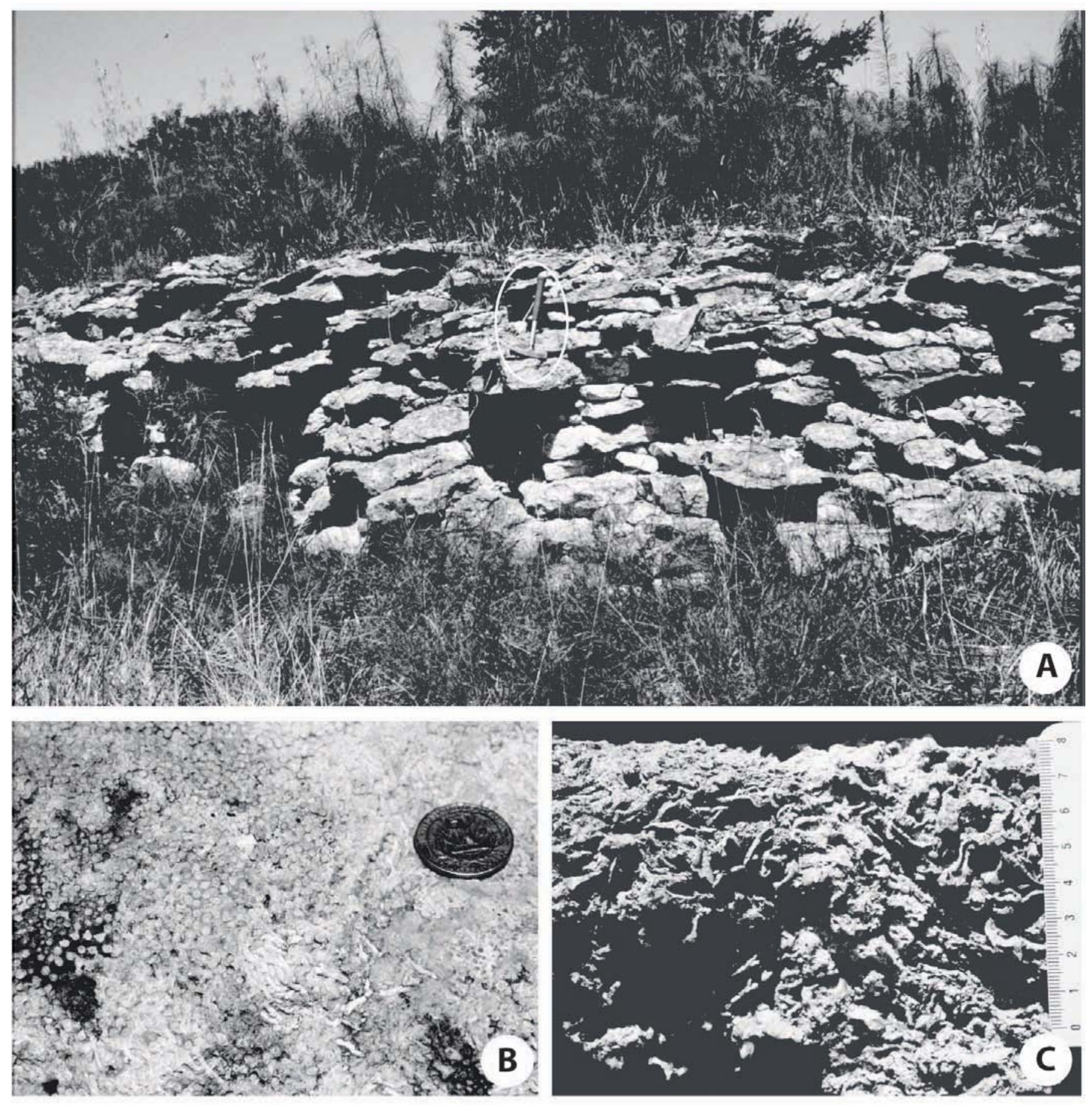

FIG. 7.- Photographs of Winterset limestone features at locality east of Chanute (Fig. 6). A) Massive to poorly bedded algal buildup thinning to the right in upper part of the section in Figure 6A. Hammer encircled (middle) is approx. $30 \mathrm{~cm}$. B) Surface view of part of a syringoporid coral mound framestone showing close corallites preserved in growth position. Individual mounds are 0.25 $\mathrm{m}$ thick, $0.4 \mathrm{~m}$ long, and aligned at the same level horizontally (Figure 6B). Coin is $2.4 \mathrm{~cm}$ in diameter. C) Large, undulatory algal thalli that fit the potato-chip description of Wray (1964). Loosely packed undulating thalli enclose multiple pores and a highly diverse biota of bryozoans and brachiopods. Scale in centimeters. 


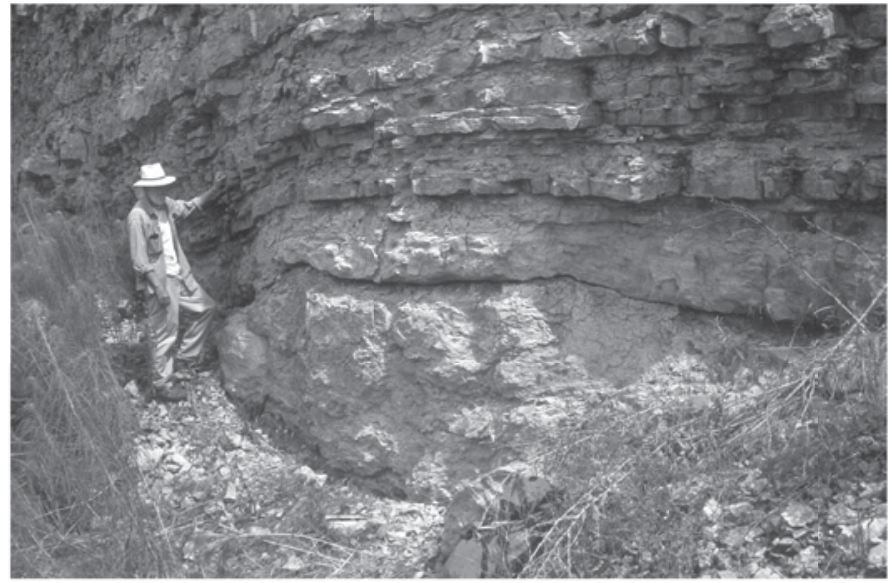

FIG. 8.-Frisbie limestone mound, as exposed in a roadcut exposure at intersection of Holliday Drive and I-435; West half of NE 1/4, Sec. 6, T.12S., R.22E., Johnson-Wyandotte County line, Kansas, p. 105-114 in Watney et al. (1989) (see Samankassou and West, 2002). Note the primary depositional relief to the right of Ron West's knee, as indicated by the draping of bedded limestone over the uneven top of the mound.

minifers. Other fossils include gastropods and rare crinoids and brachiopods.

A vertical zonation is obvious, but the facies and fossil successions differ slightly from those classically described from Pennsylvanian buildups by Wilson (1975).

\section{Captain Creek Limestone Member}

The Captain Creek Limestone Member is the lowest member of the Stanton Limestone (Fig. 2) and represents the transgressive limestone of the Stanton cyclothem. It is thicker than most of the other transgressive limestones in Kansas. Where algal limestone occurs, the Captain Creek limestone may reach a thickness of 18 $\mathrm{m}$ (Zeller, 1968, p. 33). The section studied is approximately $5 \mathrm{~m}$ thick (Figs. 14A, 15B), and variation in thickness is apparent along the roadcut where it was studied.

The lowermost part of the section is $20-60 \mathrm{~cm}$ of grayish and yellowish bedded limestone (Benedict limestone bed) with intercalations of gray shale (Figs. 14A, 15A). The limestone is an oncolitic wackestone and packstone (Fig. 14B). Heckel (1975) reported "Osagia" encrustation in this interval at a nearby locality. Fossils include bivalves, gastropods, brachiopods, and bryozoans, most of which are large.

The lower $0.3 \mathrm{~m}$ of the buildup is an algal wackestone and packstone with undulatory thalli, and the transition to the overlying cup-shaped algal boundstone is subtle (Fig. 15A).

Both undulatory and cup-shaped algal thalli built boundstones in this mound (Figs. 14C, 15B). Most of the identifiable algal thalli here show structures typical of Anchicodium and Eugonophyllum?. Many thalli are encrusted by Archaeolithophyllum lamellosum (Fig. 14B). Peloids are common, vary in dimension and form, and represent $>20 \%$ of the rock volume (Fig. 16B-D). Peloid-rich cavity fillings exhibit upward coarsening (Fig. 16A, C). Cement occurs predominantly in the sheltered pores beneath thalli (Fig. 16A; see also Harbaugh, 1960; Heckel and Cocke, 1969; Heckel, 1975) and includes thin "filaments" (similar to cyanobacteria of Kirkland et al., 1998, fig. 11, and pieces of perithallus of Heckel and Cocke, 1969, fig. 9), and is overall less abundant relative to the
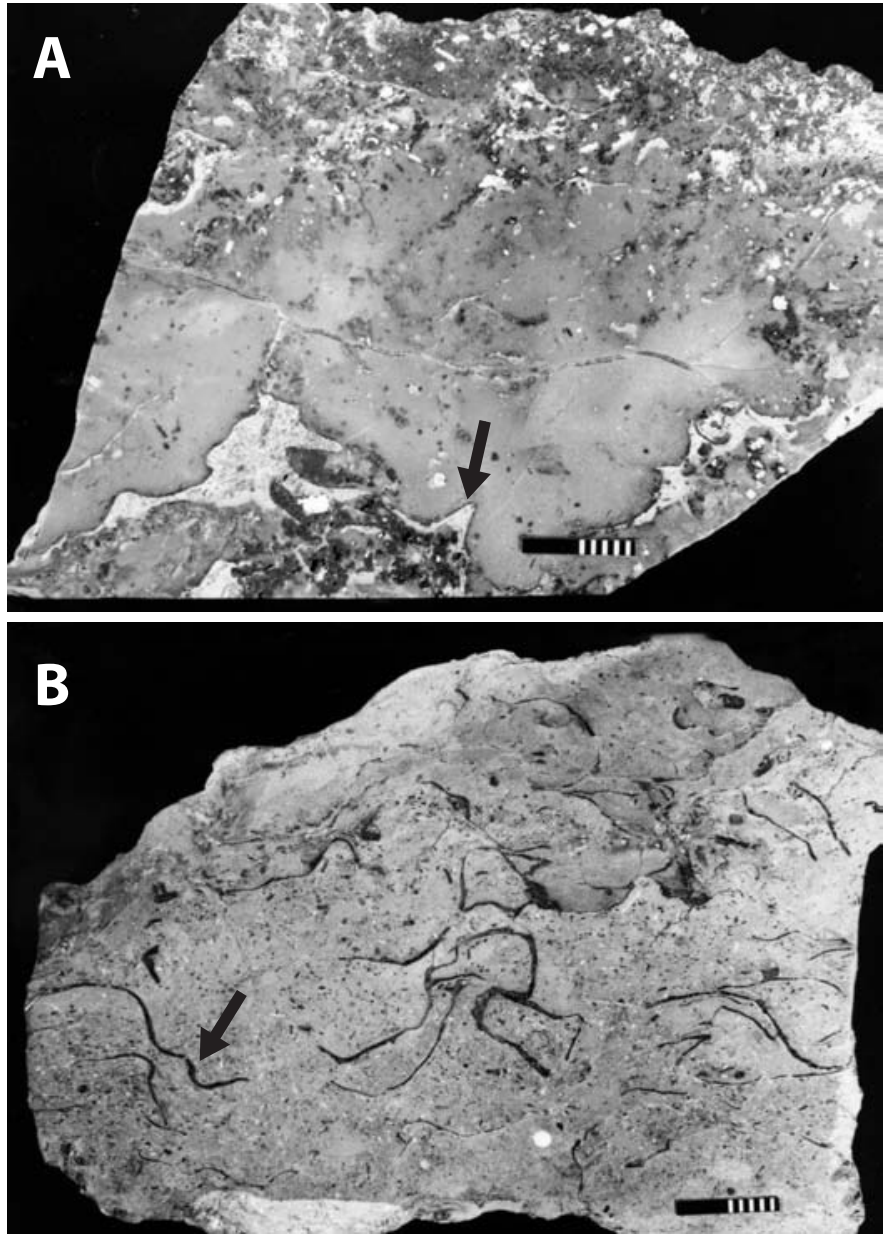

FIG. 9.-Polished slabs of Frisbie limestone mound and overlying non-mound facies. A) Polished slab from Frisbie mound facies showing large algal thalli (arrow) filled with peloidal micrite and underlain by cement (white) above sediment filling. Scale bar in centimeters. B) Polished slab of undulating thalli from overlying non-mound facies (Argentine Limestone). These algal thalli(arrow) do not show distinct orientation, suggesting simple accumulation in a uniform matrix. Scale bar in centimeters.

buildups described above. Thartharella-like structures thought to be worm tubes occur in the peloidal clotted areas that commonly filled the algal cups and cavities (Fig. 16C). As noted in the Frisbie limestone mounds, fragments of algal thalli rarely occur in the cup cavities. The mode of construction of the buildups composed of in situ algal cups and undulating growth forms in the Captain Creek differs from those described above in that: (1) the cups are scattered and are neither close to nor above each other (as in the Frisbie limestone), and (2) $>50 \%$ of the cavities remain open (Fig. 15B) and others contain dark pyrite-rich mud. Solitary corals, bryozoans, and gastropods, mostly in situ, occur along the walls of the cavities (Fig. 15B-D).

\section{CHARACTERISTICS OF DIFFERENT MOUND CONSTRUCTIONAL TYPES AND THEIR INTERPRETATION}

On the basis of form, size, composition, fossil diversity, and framework pores, three types (modes) of algal buildups are 


\section{Frisbie Limestone}
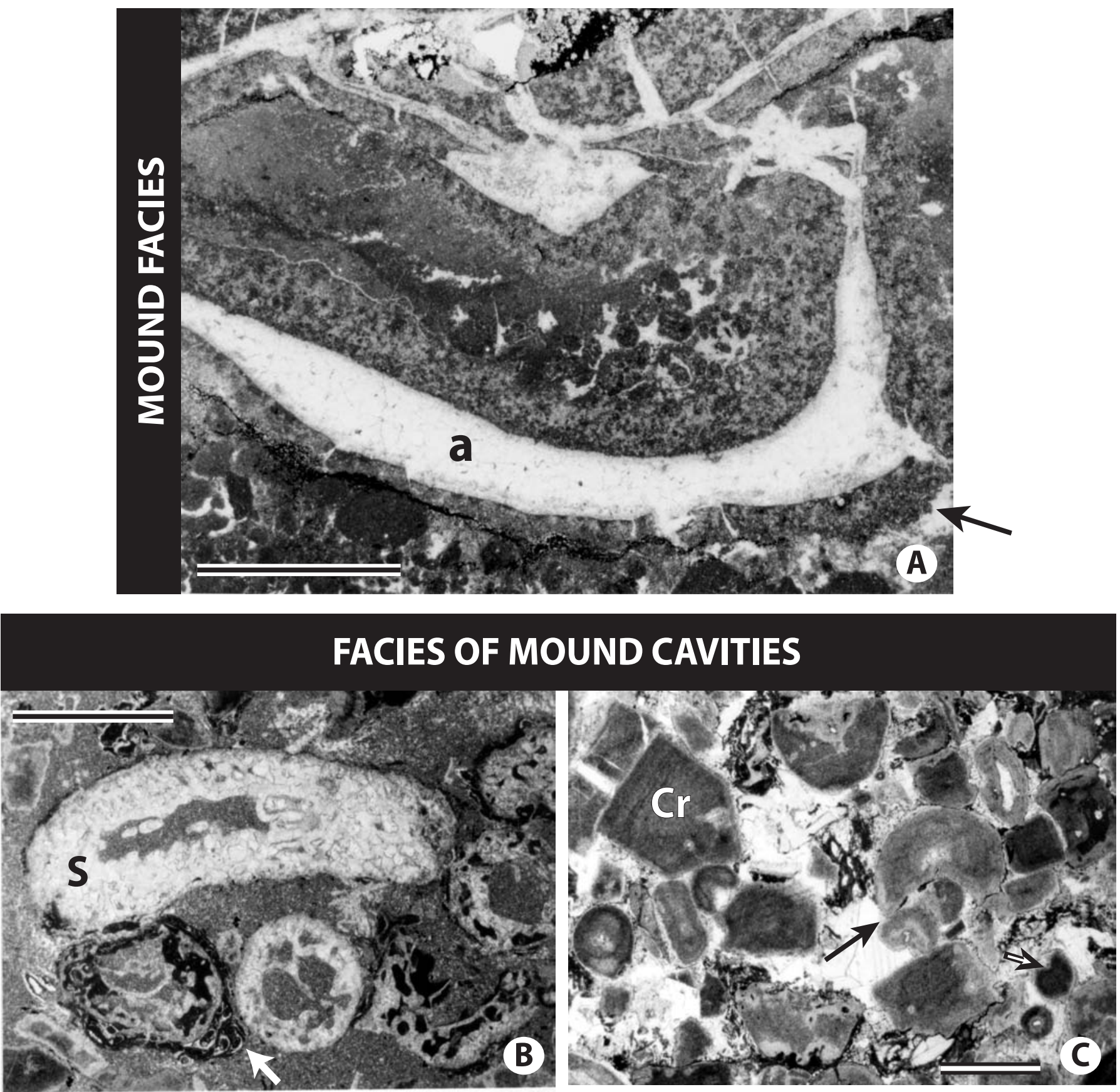

FIG. 10.-Photomicrographs of Frisbie limestone mound facies. A) Characteristic cup-shaped neomorphosed algal thallus (a) filled with and surrounded by fine-grained peloidal matrix that grades upward into coarse peloidal grains above thallus. Microbial encrustation on undersides of cup-shaped thallus in growth position (arrow). Scale bar is $5 \mathrm{~mm}$. B) Inozoan calcareous sponges (S), partly encrusted by Shamovella and sessile foraminifers (arrow). Scale bar is $5 \mathrm{~mm}$. C) Crinoid fragments (Cr: partly abraded, arrows). Both sponges and crinoids occur in cavities within larger mounds (see Samankassou and West, 2002, for details.) Scale bar is $2 \mathrm{~mm}$. 


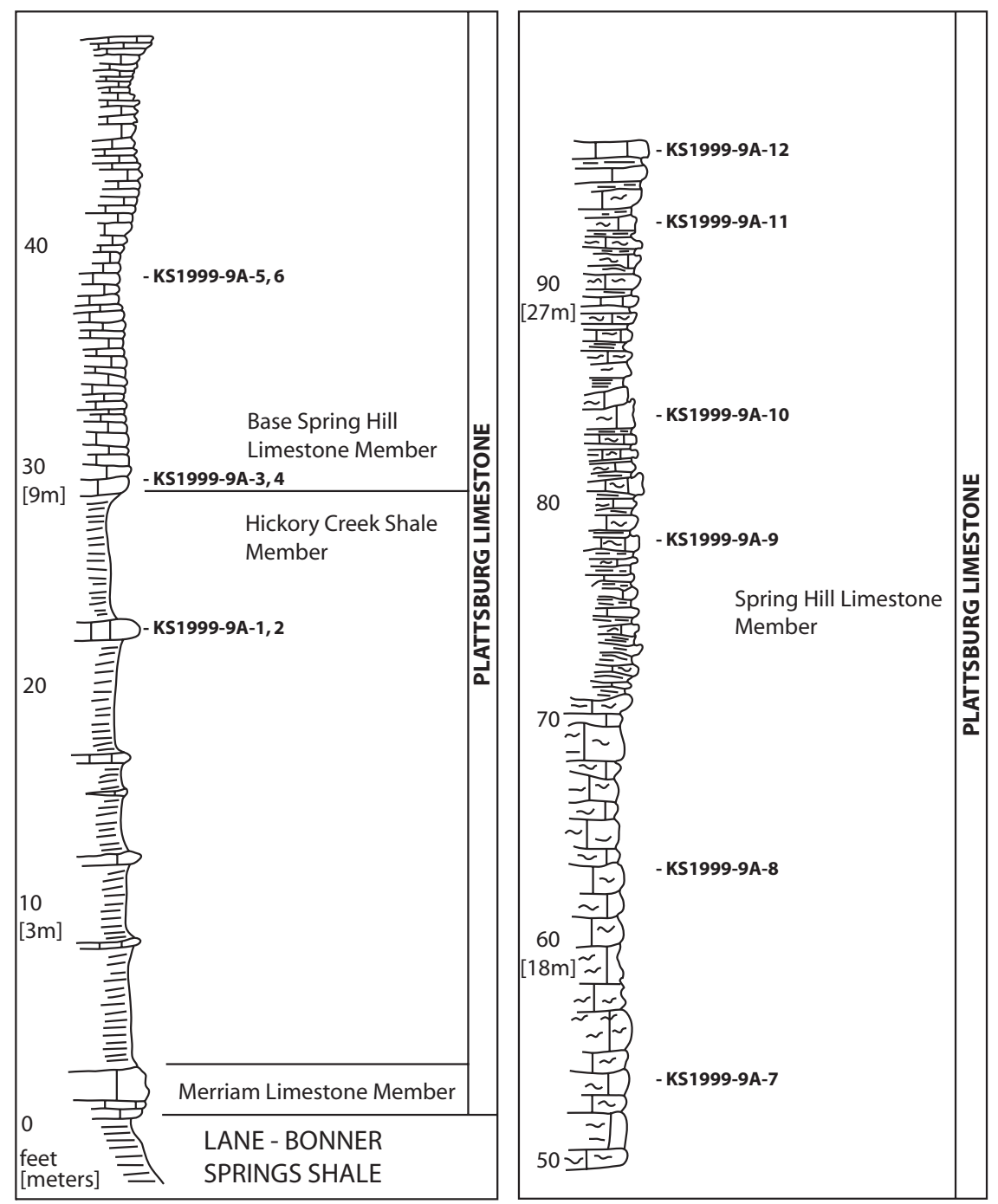

FIG. 11.-Log of exposure of Spring Hill limestone at roadcut along Kansas Highway 96 southwest of Neodesha, Kansas; SW1 / 4, SE1 / 4, Sec. 23, T.30S., R.15E., Wilson Co., Kansas, p. 30-31 in Harbaugh (1962) showing location of samples KS1999-9A-1 to KS19999A-12. Figure 12 shows indistinctly bedded limestone from 50 to 70 feet on this log. A section of the Spring Hill limestone, approximately from the same outcrop and including interpreted depositional environment, is given in Heckel (1978).

recognized in the five limestone members at the localities studied. These are: (1) mounds of cup-shaped algae, (2) mounds constructed by undulatory algal thalli, and (3) mounds of accumulated undulatory algal thalli.

\section{Type 1: Mounds Constructed of Cup-Shaped Algal Thalli}

These buildups are generally isolated bioherms a few decimeters to a few meters thick and of similar lateral extant. Fossils in these mounds have a low biotic diversity and consist of cupshaped phylloid green algae that grew closely packed and juxtaposed next to and above one another. Intercup cavities are characteristic. When composed of juxtaposed smaller mounds (e.g., Frisbie "mini-mounds"), they include intermound cavities that are filled with a diverse biota of sponges, crinoids, and bryozoans. Cup-shaped algal thalli grew near enough to each other to form a framework. Apparently, the algae of this unique bioconstruction excluded other biota, as indicated by the low diversity of other organisms (see Toomey, 1980, for discussion of low diversity in mound facies). The framework protected the intramound areas, and intercup voids contain various fillings, such as irregular grains, uniform peloidal sediment, early marine cements, and homogeneous mud (Samankassou and West, 2002). These algae built small bioherms rather than large, kilometerscale banks.

This facies is similar to that described by previous workers (e.g., Harbaugh, 1959, 1960, 1962; Crowley, 1969; Heckel and Cocke, 1969), although they did not recognize the particular growth mode. The microfacies of the Captain Creek limestone mound, as illustrated by Heckel and Cocke (1969, fig. 7), is comparable to that of a cup-shaped algal mound. Furthermore, these authors reported brachiopods, bryozoans, echinoderms, and gastropods, rare within the mound facies, from channel-like deposits within or capping the mound complexes (e.g., Heckel 

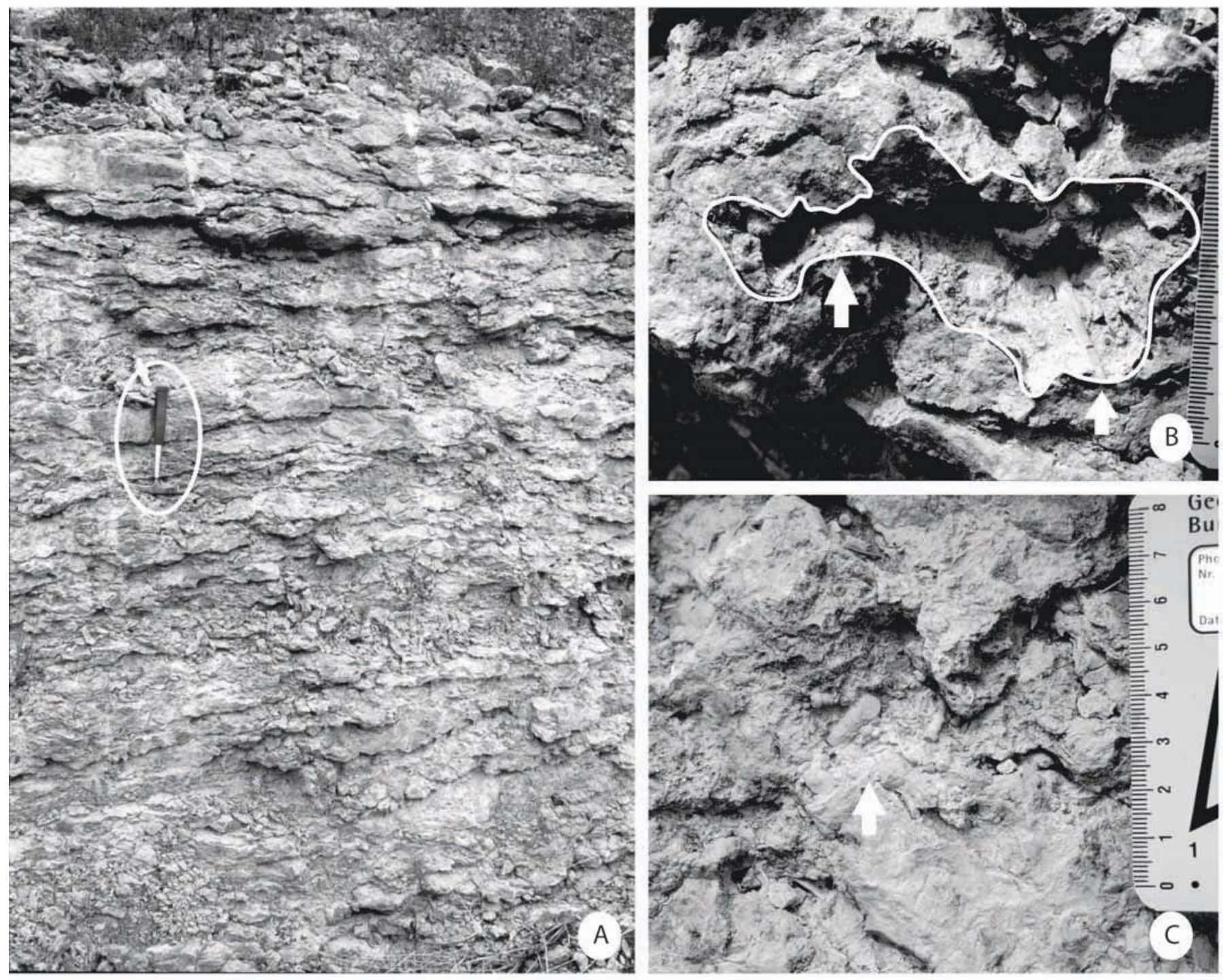

FIG. 12.-Photomicrographs of Spring Hill limestone at Neodesha. A) Indistinctly bedded limestone from 50 and 70 feet in Fig. 11 ). Hammer (encircled) is approx. $30 \mathrm{~cm}$ long. B) Large, irregular open cavity, containing bryozoans (arrow left) and crinoid fragment (arrow right). Note that cavities were not later filled with spar. Some of these cavities had shale fillings when this exposure was fresher (P.H. Heckel, personal communication). Scale bar in centimeters and millimeters. C) Detail of a cavity containing several fragments of crinoids (arrow). Scale bar in centimeters.

and Cocke, 1969, fig. 12). Some of these may be analogous to the fossil-rich intermound "voids" described from the Frisbie Limestone Member.

\section{Type 2: Mounds Constructed by Undulatory Algal Thalli}

These may include most mounds assigned to the "potato chip" model of Konishi and Wray, 1961, and Wray, 1964). Medium- to large-scale (tens of meters to kilometers in lateral extent) banks predominate, and the high biotic diversity includes bryozoans and sponges as important mound builders. The red alga Archaeolithophyllum is the dominant fossil. The characteristic "framework" pores occur as predominantly sheltered voids beneath thalli fragments, and many of these are still open space today. Wavy, crudely growing thalli of Archaeolithophyllum formed a framework that created multiple voids, especially those referred to as "umbrellas" (e.g., in Spring Hill limestone). Apparently, these algae did not totally colonize and dominate the seafloor (as did the cup-forming phylloid green algae of Type 1 mounds) because the biotic diversity is higher: bryozoans, brachiopods, and calcareous sponges are not limited to the small intermound areas (voids) as they are in Type 1 mounds. According to Toomey (1980, p. 249), "growth rates for crustose phylloid algae do not appear to be as rapid as those of the erect phylloids of the Ivanovia-Eugonophyllum group, thus substantial areas of the sea bottom were available for colonization that may be considered a 'normal' large-organism community". Thus, the crustose and crinkly growth habits of red algae in Type 2 mounds obviously favored the growth of low-relief banks rather than small bioherms (Type 1 mounds). 
As interpreted by Wray (1964), the red alga Archaeolithophyllum formed rigid crusts, which were self-supporting. Extant red algal mounds exhibit similar growth forms and internal structures (Bosence, 1991). The red alga Peyssonnelia (Squamariacea) has similar foliate growth forms and built a framework very similar to that of Archaeolithophyllum (Wray et al., 1974; James et al., 1988).

\section{Type 3: Mounds of Accumulated Undulatory Algae}

The biota in these mounds is moderately diverse, and both green and red algae contributed to this mound type. The mud
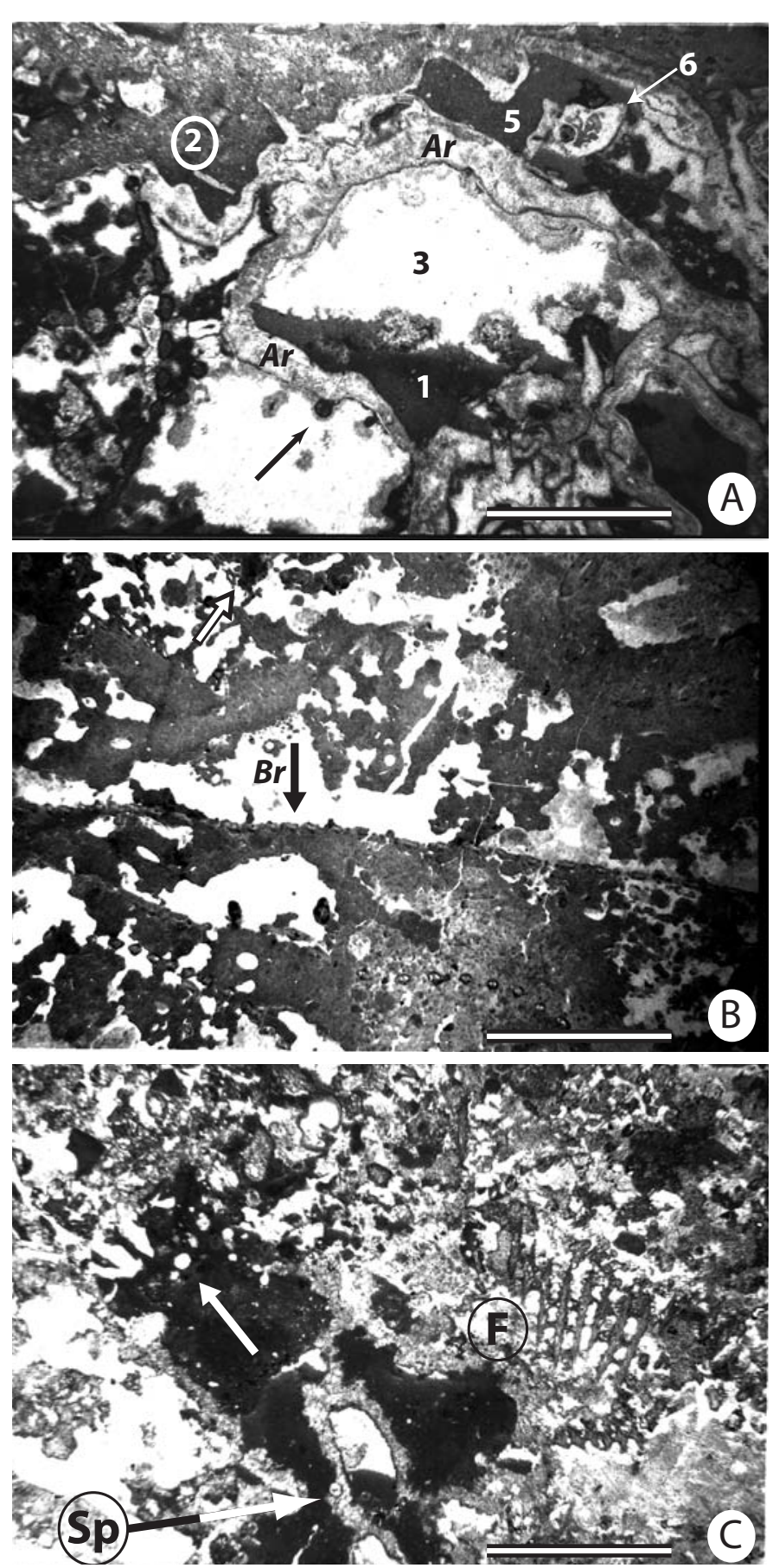

matrix is commonly uniform, and the sparse pores lack the characteristic peloidal clotted matrix and micritic cements of Type 1 mounds. Algal thalli seem to have accumulated mechanically in a muddy environment (see discussion in Samankassou and West, 2002). The small broken thalli suggest limited transport perhaps mainly by bottom feeders and scavengers, and the rare occurrence of cavities and related features suggests an absence of constructional forms. This may be explained by generally shallow-water conditions, such that wave action inhibited the growth or preservation of cups. Furthermore, the rocks overlying the mounds were deposited in a shallower environment (e.g., upper Spring Hill limestone) (Heckel and Cocke, 1969). The influence of currents reported from other examples of mounds appears to be related to Type 3 mounds, e.g., the striking megaripples illustrated by Hamblin (1969) from mounds in the Iola Limestone. How thalli accumulated to form a positive depositional relief is not clear, but longdistance transport of thalli appears to be limited (see Heckel and Cocke, 1969).

The facies in Type 3 mounds is different from that recorded by the accumulation of broken algal thalli in the inter-mound and off-mound facies of Types 1 and 2 mounds in that boundstone, cavities, and pores are absent in these associated algal-rich facies of the other mound types.

\section{Potential Extrinsic Controlling Factors}

One of the five limestones studied (Spring Hill) contains evidence of shoal water at the top of the mound, as reported from several Pennsylvanian mounds (Heckel and Cocke, 1969; Wilson, 1975; Toomey and Babcock, 1983). Thus, multiple factors seem to have controlled the evolution and termination of mound growth, e.g., sea-level rise (probable for mounds of the Frisbie limestone, a transgressive limestone within the cyclothem; Heckel, 1999; Samankassou and West, 2002), tectonics, or terrigenous clastic influx (Heckel and Cocke, 1969; Heckel, 1975) associated with climatic changes. This topic is beyond the scope of this paper, and will be treated in a subsequent paper.

The study of algal mounds needs to be expanded to other formations in Kansas, as well as to other states and countries, so

\section{$\leftarrow$}

FIG. 13.-Photomicrographs of Spring Hill limestone. A) Archaeolithophyllum red algal boundstone from level 30 feet, sample KS 1999-9A-3 in Fig. 11. Branched thalli $(A r)$ form a framework that encloses multiple cavities floored with fine sediment $(1,5)$ and peloidal mud $(2)$, and lined with fibrous marine cement (3) as indicated by enclosed fossils (sponges marked 6 or at roof of large void above 3). Note pendant micritic cement lined by fibrous rim (arrow). Scale bar is 5 mm. B) Archaeolithophyllum-bryozoan boundstone from level 30 feet, sample KS 1999-9A-3 in Fig. 11. Archaeolithophyllum is intertwined with bryozoans (fronds marked $\mathrm{Br}$ and black arrow). Note irregular and patchy distribution of micritic cements (some are gravity-defying; white arrow), irregular surface of peloidal fillings, and the blocky cement (white), the last phase of void filling that represents $>30 \%$ of rock volume. Scale bar is $5 \mathrm{~mm}$. C) Bryozoan boundstone from level 90 feet, sample KS 1999-9A-11 in Fig. 11. Fenestellid bryozoan (F) and Thartharella? (white arrow), a probable worm tube, enclose multiple voids in peloidal matrix. Larger voids are filled with micritic cement (dark) that enclosed marine fossil (e.g., sponge $\mathrm{Sp})$. Scale bar is $5 \mathrm{~mm}$. 


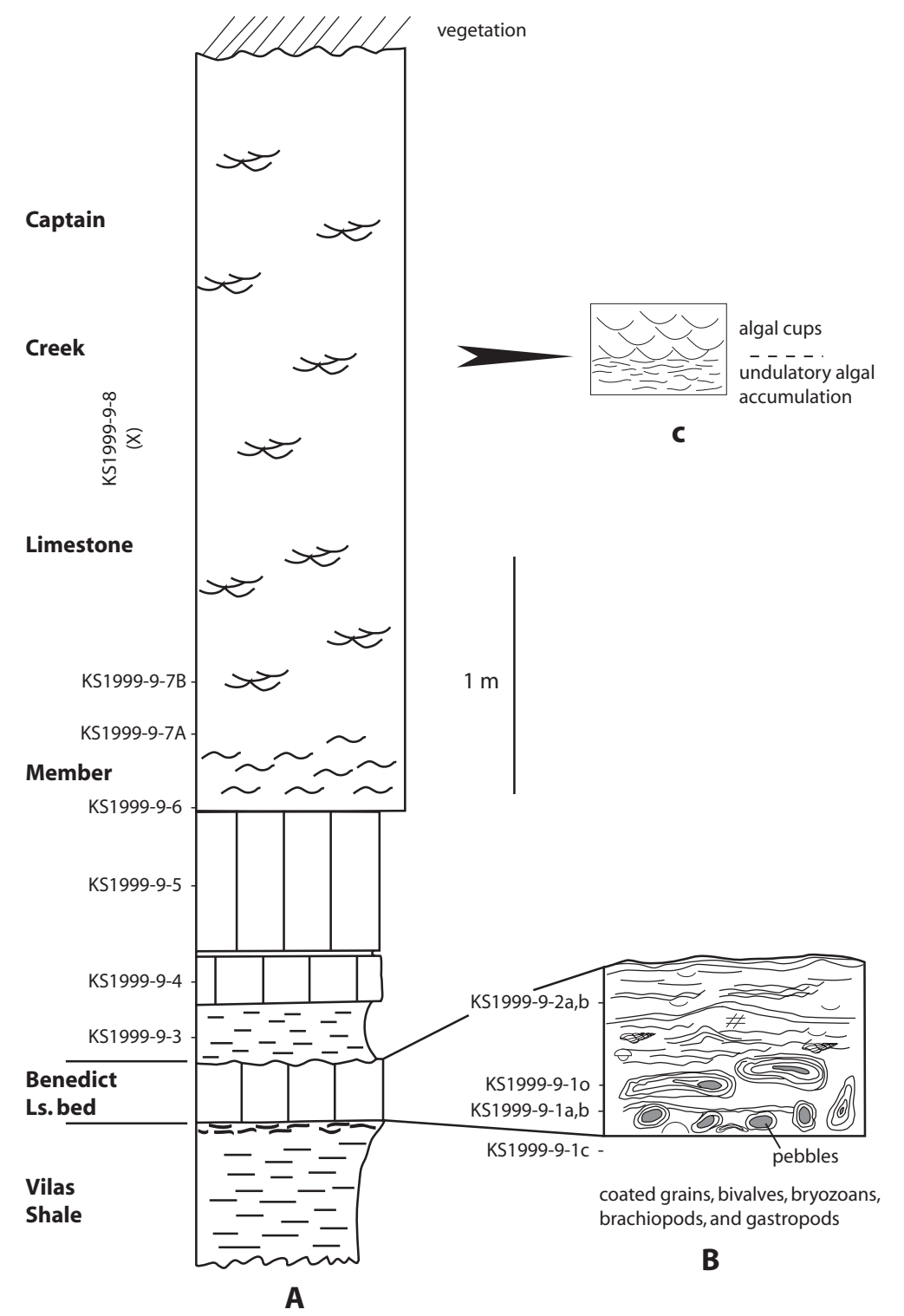

FIG. 14.-Log of exposure of Captain Creek limestone at roadcut along U.S. Highway 400 northwest of Neodesha, Kansas; near Center of North half, Sec. 1, T.30S., R.15E.,Wilson Co., Kansas; see also discussion and sections in Harbaugh (1962) (see Figure 1 for location). Sketched section corresponds approximately to field view shown in Figure 15A. Accumulation of undulatory algal thalli and coated grains characterize basal part of section (B). Both undulatory and cup-shaped phylloid algal thalli dominate lower part of buildup (C).

as to identify the spectrum of algal-mound formation and to differentiate among them. A quantitative approach may help to better evaluate the role of early cementation, the contribution of microbes to mound construction, and whether a distinct type of porosity is associated with or linked to specific types of mound buildups. Also, extensive study of thin sections is needed to determine the taxa involved to determine if different mound types are related to specific algal taxa.

\section{CONTRIBUTION OF MICROBIAL ACTIVITY}

Many features of the peloidal clotted matrix that is common in most algal mounds studied suggest a biogenic origin. These include: (1) the domal forms (Figs. 16D, 17A); (2) the irregular surface of mud in cavities created by the algal thalli, which could hardly have resulted from the mud settling through the water column as a mud "rain" (Figs. 13A-C; 16C, D); (3) the patchy distribution, where the peloidal areas are different from the nearby matrix (Figs. 13B, 16C, 16D); and (4) the encrustation around all sides of an algal thallus (Fig. 10A), which probably contributed to stabilization of the framework.

As in many fossil mounds, the role of microbes in mound construction can be inferred only from the widespread clotted peloidal structure of the matrix, which is currently assumed to have resulted from microbial activity (e.g., Macintyre, 1985; Chafetz, 1986; Chafetz and Buczynski, 1992; Pratt, 1995).

Microbes also seem to have played an important role in carbonate production and lithification. In the Sniabar lime- 

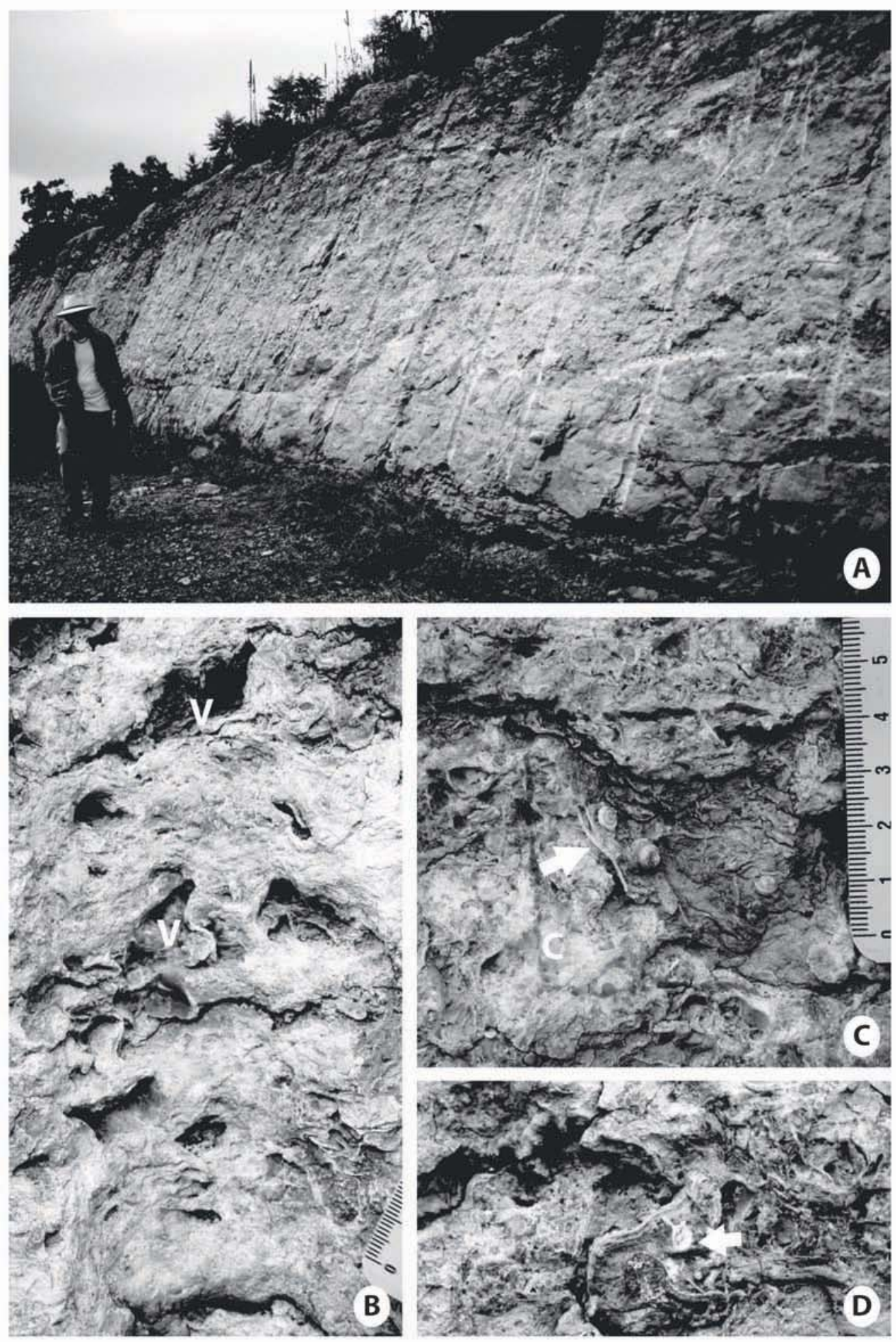

FIG. 15.-Field photographs of Captain Creek limestone. A) Field view of main part of thick Captain Creek limestone exposed along U.S. Highway 400, northwest of Neodesha, Kansas (see measured section in Figure 14). Thickening to right on photograph is real and not due to dip. Ron West for scale. B) Undulatory algal thalli enclosing multiple open, irregular cavities at various levels of KS 1999-9-8 (X) in Fig. 14. Some cavities (V) are actually primary open spaces that have persisted since the rock was formed (cf. similar reports by Murray, 1960). Scale bar in millimeters. C) Detail of open space cavities lined with cement (C) and containing fossils (solitary corals, arrow). Scale in centimeters. D) Small solitary coral attached to an algal thallus. Other fossils that occur in the cavities are bryozoans, gastropods, and sponges (not visible at this resolution). Such fossils may represent actual cryptic biota. Note loosely packed, partly in situ but brecciated algal thalli. Picture at same resolution as Part C. 

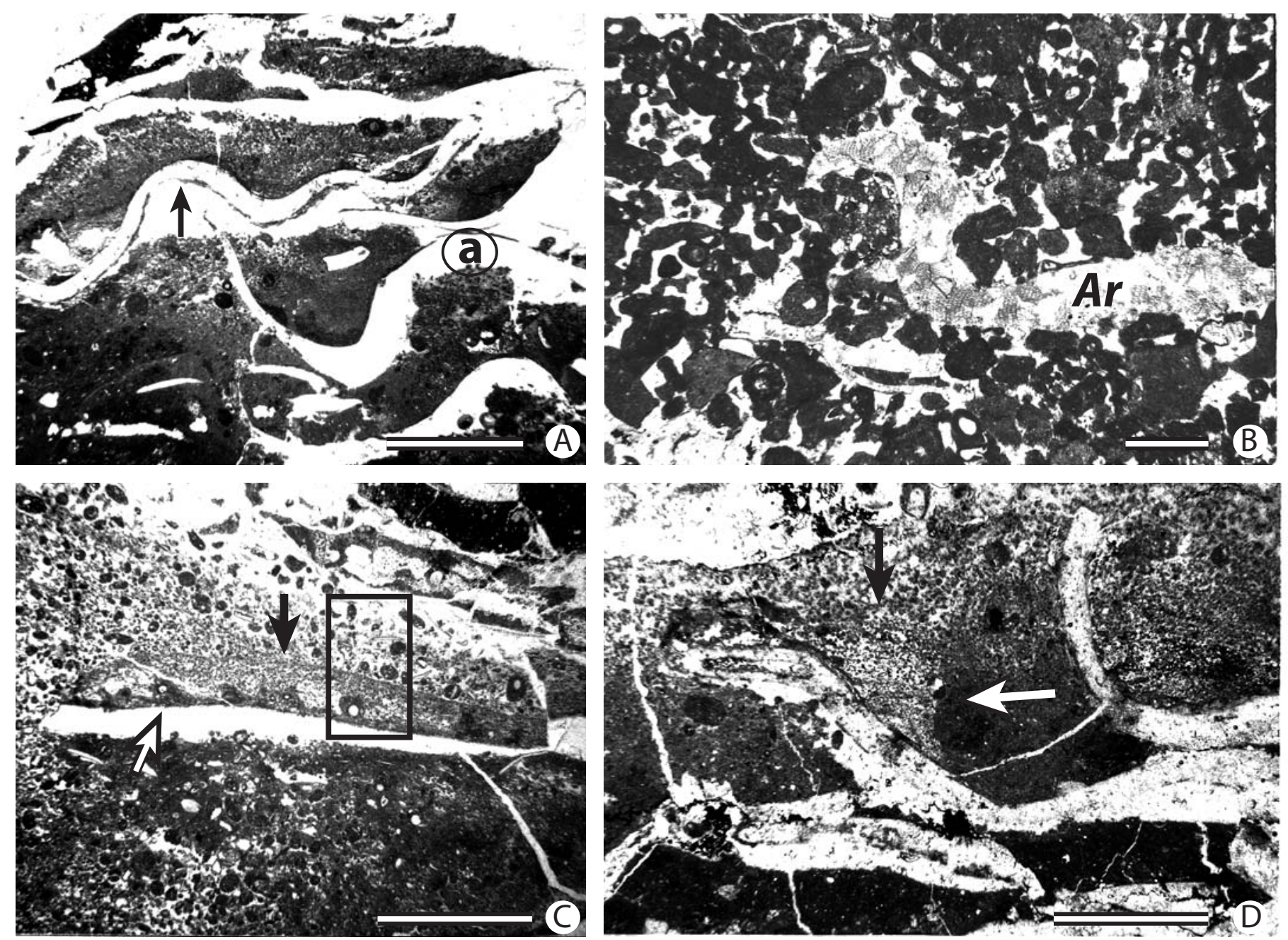

FIG. 16.-Photomicrographs of Captain Creek algal facies. A) Boundstone of undulatory algal-constructional mound. Curved, large thalli of green algae (a) shelter cavities below thalli. Upper side is covered with peloidal mud. Cavities obviously remained open, as undersides of blades are encrusted (thin dark layer, arrow). Scale bar is $5 \mathrm{~mm}$. B) Red alga Archaeolithophyllum (Ar, network of cells) in matrix of peloidal grainstone. Scale bar is $1 \mathrm{~mm}$. C) Intermediate type with accumulation of undulatory thalli and early cemented matrix. Framework is not obvious. Nevertheless, peloidal matrix show several "growth" stages (rectangle): (1) peloidal mud, around Thartharella (white arrow) thought to be a worm tube, limited to upper surface of algal thalli (dark arrow); (2) packstone to grainstone including peloids that are larger than those of first stage; (3) grainstone including larger peloids. Scale bar is $5 \mathrm{~mm}$. D) Curved thalli of algae surrounded by peloidal mud. Note small-scale upward coarsening in peloidal infillings and domal form of the peloidal grainstone with high angle of repose (black and white arrows). Scale bar is $5 \mathrm{~mm}$.

stone, sponge-like structures overgrown by algae include thin "filaments" (Fig. 5B) interpreted as precipitation associated with cyanobacteria (see Kirkland et al., 1998, fig. 11). Such structures represent about $50 \%$ of the rock volume in samples from this interval, contributing to the carbonate budget of the resulting buildups. Cements in voids also include filaments (Fig. 17A) of possible microbial origin. Micritic encrustations similar to those reported from the Permian Capitan Reef (Texas and New Mexico, U.S.A.) and interpreted as microbial in origin (Kirkland et al., 1998, fig. 7D) occur on botryoids within cements of two of the three mound types (Types 2 and 3 in the Spring Hill and Captain Creek Limestone Members) recognized in this study (Fig. 17B, C).

\section{CONCLUSIONS}

This detailed study of selected algal-dominated buildups from five stratigraphic intervals in the Pennsylvanian of eastern Kansas, U.S.A., has revealed three basic mound growth modes.

Type 1. Mounds of cup-shaped in situ algal growth with low biotic diversity are dominated by phylloid green algae that typically form small bioherms as either isolated (e.g., Frisbie limestone mound) or thickened intervals within carbonate banks (e.g., Sniabar limestone mound). Commonly, these are composites of coalescent smaller mounds (mini-mounds), which are separated by larger cavities. Mud and cement fill the abundant intercups voids within the mini-mounds. Calcareous sponges, 

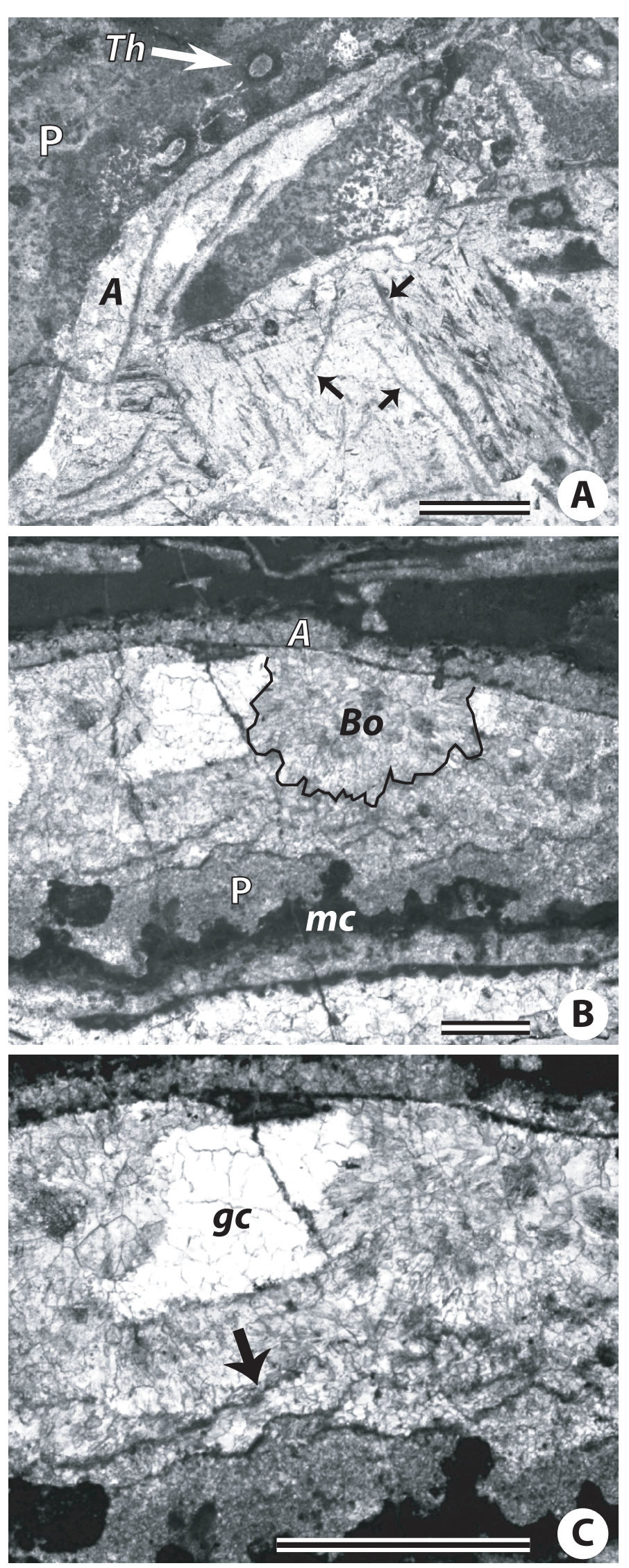

crinoids, and bryozoans, probably cavity dwellers, fill the larger intermound cavities between the mini-mounds.

Type 2. Constructional mounds of algae with undulatory growth forms, basically of red algae with recognizable thalli characteristics of Archaeolithophyllum (e.g., Spring Hill limestone mound), and only rarely of phylloid green algae (e.g., parts of the Captain Creek limestone mound). These buildups are commonly laterally persistent. Relief is recognizable only at a large scale (tens of meters to kilometers). Fossil diversity is high, with calcareous sponges, brachiopods, and bryozoans as the common mound fossils in this type, but which occur exclusively in cavities between mounds of the cup-shaped algal type (1). Solitary corals, calcareous sponges, and bryozoans occur attached to the walls of the cavities. The occurrence of cavities that are still open is striking.

Type 3. Mounds of accumulated algae with undulatory growth forms are of the red algae Archaeolithophyllum missouriense, and Archaeolithophyllum lamellosum and of the green alga Eugonophyllum?. Depositional relief, not visible on the outcrop, is inferred from large-scale variations in bank thickness (e.g., lower part of Captain Creek mound). Biotic diversity is intermediate between the previous types. Multiple cavities, commonly cement-filled, occur.

The presence of peloidal clotted matrix, most probably microbial in origin, that accumulated in specific areas, is common to all mound types.

Mound characteristics, principally dimensions, form, biotic diversity, and type of porosity, seem to be linked to the type and growth form of specific algae, although no systematic relationship can be deduced clearly at this stage of the study. The same is valid for the controlling factors, principally sea-level change and clastic input associated with climatic change and tectonic effects, which are the focus of a subsequent study.

\section{ACKNOWLEDGMENTS}

ES thanks P.H. Heckel (Iowa, U.S.A.) for information he provided during a 1999 fieldtrip in the Midcontinent of the U.S. The thorough reviews and constructive suggestions of Phil Heckel, Lynn Soreghan, an anonymous referee, and editor Ian Somerville improved the first draft. The patience and efforts of the editorial team to include this contribution in the present volume is gratefully acknowledged. John Southard and Bob Clarke are gratefully

\section{$\leftarrow$}

FIG. 17.-Photomicrographs illustrating microbial activity in mound facies. A) Thin "filaments" (dark arrows pointing to dark lines) occurring in cement filling voids of algal boundstone. Surface of algal thallus $(A)$ is encrusted by peloidal mud, probably bound on the surface of algal thallus by bacteria and Thartharella (Th, white arrow). Note the latter area, which is darker compared to the "normal" peloidal matrix $(\mathrm{P})$. These structures resemble fragments of perithalli illustrated in Heckel and Cocke (1969, fig. 9). From sample KS 1999-9-8, Captain Creek Limestone Member (see Fig. 14). B,C) Algal thalli $(A)$ overgrown by micritic cement $(m c)$ irregular in shape and botryoidal cement $(B o)$. Thin crusts (arrow in C) on the surface of botryoids represent microbial crusts (Kirkland et al., 1998, fig. 7D). Peloidal mud (P) filled the residual voids. Residual pores between botryoids probably resulted from solution and was later filled with spar (gc). From sample KS 1999-9A-7, Spring Hill Limestone Member (see Fig. 11). Scale bar is $2 \mathrm{~mm}$ for all photomicrographs. 
acknowledged for their editorial suggestions, which greatly improved the final manuscript. Financial support from the German Research Foundation (Deutsche Forschungsgemeinschaft, DFG), Bonn, Germany through grants FL $42 / 72$ and SA 652/1 to ES is acknowledged. ES also benefited from a grant from the Swiss National Science Foundation (Project No 20-56491.99) during the final draft of the paper.

\section{REFERENCES}

BosenCE, D.W.J., 1991, Coralline algae: mineralization, taxonomy, and palaeoecology, in Riding, R., ed., Calcareous Algae and Stromatolites: Berlin, Springer-Verlag, p. 98-113.

ChAfetz, H.S., 1986, Marine peloids: a product of bacterially induced precipitation of calcite: Journal of Sedimentary Petrology, v. 56, p. 812-817.

CHAFETZ, H.S., AND BUCZYNSKI, C., 1992, Bacterially induced lithification of microbial mats: Palaios, v. 7, p. 277-293.

Crowley, D.J., 1969, Algal-bank complex in Wyandotte Limestone (Late Pennsylvanian) in eastern Kansas: Kansas Geological Survey, Bulletin $198,52 \mathrm{p}$.

FAgerstrom, J.A., 1987, The Evolution of Reef Communities: New York, John Wiley \& Sons, 592 p.

Felton, R.M., AND HeCKEL, P.H., 1996, Small-scale cycles in Winterset Limestone Member (Dennis Formation, Pennsylvanian of northern Midcontinent) represent "phased regression", in Witzke, B.J., Ludvigson, G.A., and Day, J., eds., Paleozoic Sequence Stratigraphy; Views from the North American Craton: GeologicalSociety of America, Special Paper 306, p. 389-397.

Frost, J.G., 1969, A carbonate bank (Pennsylvanian) in southeastern Kansas: Kansas Academy of Science, Transactions, v. 72, p. 237-291.

Frost, J.G., 1975, Winterset algal-bank complex, Pennsylvanian, eastern Kansas: American Association of Petroleum Geologists, Bulletin, v. 59, p. 265-291.

Hamblin, W.K., 1969, Marine paleocurrent directions in limestones of the Kansas City Group (Upper Pennsylvanian) in eastern Kansas: Kansas Geological Survey, Bulletin 194, 24 p.

Harbaugh, J.W., 1959, Marine bank development in Plattsburg limestone (Pennsylvanian), Neodesha-Fredonia area, Kansas: Kansas State Geological Survey, Bulletin 134, p. 291-331.

Harbaugh, J.W., 1960, Petrology of marine bank limestones of Lansing Group (Pennsylvanian), southeast Kansas: Kansas State Geological Survey, Bulletin 142, p. 189-234.

Harbaugh, J.W., 1962, Geologic guide to Pennsylvanian marine banks, southeast Kansas: Geoeconomics of the Pennsylvanian marine banks in southeast Kansas: Kansas Geological Society, Field Conference Guidebook, v. 27, p. 13-67.

HeCKel, P.H., 1975, Stratigraphy and depositional framework of the Stanton Formation in southeastern Kansas: Kansas State Geological Survey, Bulletin 20, 45 p.

Heckel, P.H., 1978, Upper Pennsylvanian limestone facies in eastern Kansas: Kansas Geological Survey, Guidebook Series, v. 2, p. 1-69.

HeCKel, P.H., ed., 1999, Middle and Upper Pennsylvanian (Upper Carboniferous) cyclothem succession in Midcontinent Basin, U.S.A.: Kansas Geological Survey, Open-File Report 99-27 (Field trip \#8, International Congress on the Carboniferous-Permian, Calgary, Canada), $236 \mathrm{p}$.

HeCKEL, P.H., AND CoCKe, J.M., 1969, Phylloid algal-mound complexes in outcropping Upper Pennsylvanian rocks of Mid-Continent: American Association of Petroleum Geologists, Bulletin, v. 53, p. 10581074 .

JAMES, N.P., WRAY, J.L., AND GINSBURG, R.N., 1988, Calcification of encrusting aragonitic algae (Peyssonneliaceae): implications for the origin of Late Paleozoic reefs and cements: Journal of Sedimentary Petrology, v. 58, p. 291-303.
KiRKLAND, B.L., Dickson, J.A.D., Wood, R.A., AND Land, L.S., 1998, Microbialite and microstratigraphy: the origin of encrustations in the middle and upper Capitan Formation, Guadalupe Mountains, Texas and New Mexico, U.S.A.: Journal of Sedimentary Research, v. 68, p. 956969.

Konishi, K., AND WraY, J.L., 1961, Eugonophyllum, a new Pennsylvanian and Permian algal genus: Journal of Paleontology, v. 35, p. 659-666.

MacintYRe, I.G., 1985, Submarine cements-the peloidal question, in Schneidermann, N., and Harris, P.M., eds., Carbonate Cements: SEPM, Special Publication 36, p. 109-116.

MurRAY, R.C., 1960, Origin of porosity in carbonate rocks: Journal of Sedimentary Petrology, v. 30, p. 59-84.

PratT, B.R., 1995, The origin, biota and evolution of deep-water mudmounds, in Monty, C.L.V., Bosence, D.V.J., Bridges, P.H., and Pratt, B.R., eds., Carbonate Mud-Mounds; Their Origin and Evolution: International Association of Sedimentologists, Special Publication 23, p. 49-123.

SAMANKASSOU, E., 2001, Internal structure and depositional environment of Late Carboniferous mounds from the San Emiliano Formation, Cármenes Syncline, Cantabrian Mountains, Northern Spain: Sedimentary Geology, v. 145, p. 235-252.

SAMANKASSOU, E., AND WEST, R.R., 2000, Construction versus accumulation in phylloid algal mounds: Case study from the Pennsylvanian Frisbie Limestone Member, Kansas, U.S.A. (abstract): Permo-Carboniferous Carbonate Platforms and Reefs, p. 121, SEPM-International Association of Sedimentologists Research Conference, May 12-19, 2000, El Paso, U.S.A.

SAMANKASSOU, E., AND WeSt, R.R., 2002, Construction versus accumulation in phylloid algal mounds: an example of a small constructed mound in the Pennsylvanian of Kansas, U.S.A.: Palaeogeography, Palaeoclimatology, Palaeoecology, v. 185, p. 379-389.

TEDESCO, L.P., AND WANLESS, H.R., 1989, Role of burrow excavation and infilling in creating the preserved depositional fabric of Pennsylvanian phylloid mounds of southeastern Kansas, in Watney, W.L., French, J., and Franseen, E.K., eds., Sequence Stratigraphic Interpretations and Modeling of Cyclothems in the Upper Pennsylvanian (Missourian) Lansing and Kansas City Groups in Eastern Kansas: Kansas Geological Survey, Open-File Report \# 89-44, p. 179-191.

TEDESCO, L.P., AND WANLESS, H.R., 1995, Growth and burrow-transformation of carbonate banks: comparison of modern skeletal banks of South Florida and Pennsylvanian phylloid banks of south-eastern Kansas, U.S.A., in Monty, C.L.V., Bosence, D.W.J., Bridges, P.H., and Pratt, B.R., eds., Carbonate Mud-Mounds; Their Origin and Evolution: International Association of Sedimentologists, Special Publication 23, p. 495-521.

ToomeY, D.F., 1980, History of a Late Carboniferous phylloid algal bank complex in northeastern New Mexico: Lethaia, v. 13, p. 249-267.

Toomey, D.F., AND BABCOCK, J.A., 1983, Precambrian and Paleozoic algal carbonates, west Texas-southern New Mexico: Colorado School of Mines, Professional Contributions, v. 11, 345 p.

Wahlman, G.P., 1988, Subsurface Wolfcampian (Lower Permian) shelfmargin reefs in the Permian Basin of west Texas and southeastern New Mexico, in Morgan, W.A., and Babcock, J.A., eds., Permian Rocks of the Midcontinent: SEPM, Midcontinent Section, Special Publication 1, p. 177-204.

Watney, W.L., French, J., and Franseen, E.K., 1989, Sequence stratigraphic interpretations and modeling of cyclothems in the Upper Pennsylvanian (Missourian) Lansing and Kansas City groups in eastern Kansas: Kansas Geological Survey, Open-File Report \# 8944, $211 \mathrm{p}$.

Watney, W.L., French, J., Doveton, J.H., Youle, J.C., And Guy, W.J., 1995, Cycle hierarchy and genetic stratigraphy of Middle and Upper Pennsylvanian strata in the Upper Mid-Continent, in Hyne, N., ed., Sequence Stratigraphy of the Mid-Continent: Tulsa Geological Society, Special Publication 4, p. 141-192. 
Wilson, J.L., 1975, Carbonate Facies in Geologic History: New York, Springer-Verlag, $471 \mathrm{p}$.

Wood, R., 1999, Reef Evolution: Oxford, U.K., Oxford University Press, $414 \mathrm{p}$.

Wray, J.L., 1964, Archaeolithophyllum, an abundant calcareous alga in limestones of the Lansing Group (Pennsylvanian), southeastern Kansas: Kansas Geological Survey, Bulletin v. 170, p. 1-13.

Wray, J.L., JAMES, N.P., AND GinsBURG, R.N., 1974, The puzzling Paleozoic phylloid algae: a Holocene answer in Squamariacean calcareous red algae (abstract): American Association of Petroleum Geologists and SEPM, Annual Meeting Abstracts, v. 2, p. 82-83.

ZelLer, D.E., ed., 1968, The stratigraphic succession in Kansas: Kansas Geological Survey, Bulletin 189, 81 p. 